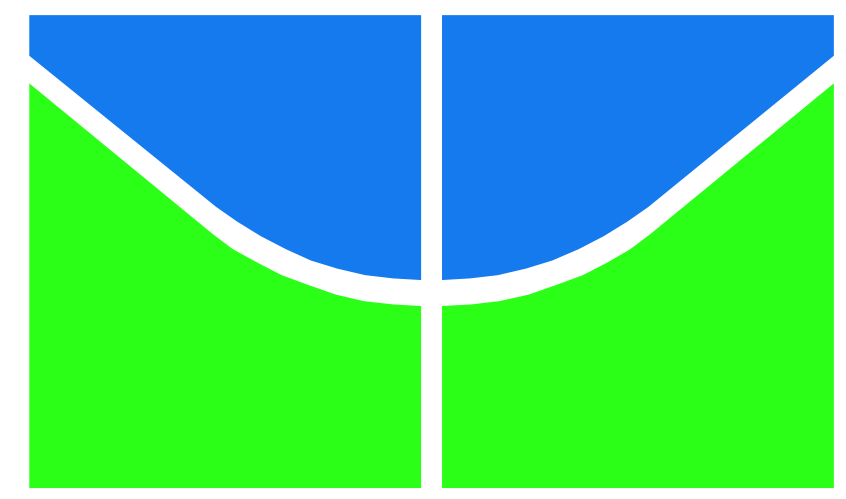

Universidade de Brasília

Instituto de Psicologia

Programa de Pós-Graduação em Desenvolvimento Humano e Saúde Área de Concentração: Desenvolvimento Humano e Educação

Linha de Pesquisa: Desenvolvimento Humano e Cultura

\title{
A PSICOLOGIA E O PSICÓLOGO DO ESPORTE: UMA FORMAÇÃO NECESSÁRIA
}

Hugo Soares Pinho 


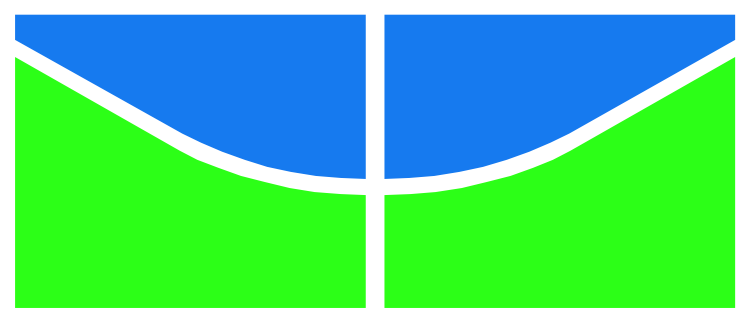

Universidade de Brasília

Instituto de Psicologia

Programa de Pós-Graduação em Desenvolvimento Humano e Saúde Área de Concentração: Desenvolvimento Humano e Educação

Linha de Pesquisa: Desenvolvimento Humano e Cultura

\section{A PSICOLOGIA E O PSICÓLOGO DO ESPORTE: UMA FORMAÇÃO NECESSÁRIA}

Hugo Soares Pinho

Dissertação a ser apresentada ao Instituto de Psicologia da Universidade de Brasília como requisito parcial à obtenção de grau de Mestre em Processos de Desenvolvimento Humano e Saúde, na área de concentração Desenvolvimento Humano e Educação.

Orientadora: Prof ${ }^{\mathrm{a}}$ Dr $^{\mathrm{a}}$ Regina Lúcia Sucupira Pedroza

Brasília, abril de 2016 
Pinho, Hugo

PP65 4p

A psicologia e psicólogo do esporte: uma formação necessária / Hugo Pinho; orientador Regina Pedroza. - Brasília, 2016.

$106 \mathrm{p}$.

Dissertação (Mestrado - Mestrado em Processos de Desenvolvimento Humano e Saúde) -- Universidade de Brasília, 2016.

1. Formação em psicologia no Brasil. 2. Psicologia do esporte. 3. Psicólogo do esporte no Brasil. I. Pedroza, Regina, orient. II. Título. 


\section{Agradecimentos}

Foram muitas as pessoas que, direta e indiretamente, me ajudaram durante esse período, com apoio, amizade e amor. A todas elas, meu sincero agradecimento. Menciono aqui apenas algumas, a quem agradeço de forma diferenciada.

À minha mãe especialmente e meu pai, que nesses dois anos estiveram presentes, apoiando, dando suporte, e incondicionalmente, construindo minha formação ao meu lado, e desde sempre.

Aos meus grandes colegas de curso, Filipe, Rafael, Murylo, David e Lais que sempre estiveram comigo e interessados na minha trajetória acadêmica. E principalmente Loyane, que durante minha graduação foi a pessoa que mais me vez crescer, amadurecer, refletir, pensar e evoluir não só como psicólogo, mas principalmente como pessoa.

Gostaria de agradecer engrandecidamente a Maiara Ribeiro, por ser a melhor companheira, pelas conversas, paciência, carinho, reflexões e ajuda tanto para o desenvolvimento da dissertação, como para o mestrado e para os aspectos gerais vividos nesses últimos dois anos.

Em especial memória ao meu grande irmão Régis, que com certeza foi, e ainda é, a pessoa que mais me influenciou como ser humano desde pequeno. O cara que me sempre fez parte dos meus processos de tornar-se. Um amigo, pai, irmão, mestre, e que mais me apoiou e me incentivou, além de estar presente em todos os momentos mais difíceis como companheiro e tutor. Que no primeiro ano do meu mestrado era a pessoa mais empolgada e incentivadora para a conclusão. Sou o que sou, em grande parte, devido aos seus ensinamentos ao longo da minha vida.

À minha querida orientadora e amiga Regina Pedroza, que, desde a graduação, tem sido uma importante referência e companheira na troca de ideias e ideais.

Agradeço também ao professor Alexandre Rezende e as professoras Gabriela Mieto e Lúcia Pulino, por aceitarem fazer parte da minha banca e por representarem para mim referências de profissionais e intelectuais.

Por fim, ao CNPq, pelo importante apoio financeiro na realização desta pesquisa. 


\section{Memorial}

Desde criança tive interesse por esportes, fui federado pelo Distrito Federal nas modalidades de natação, basquete e futebol, participando durante muitos anos de competições nacionais e internacionais. O esporte, como atleta, só foi deixado em segundo plano no final do ensino médio, com a preparação para o vestibular. Ingressei no curso de Direito em 2005, o qual tranquei após dois anos, e competia basquete pelo time da universidade. Comecei o curso de psicologia em 2007 e ainda fui durante dois anos do time de basquete.

Nesse mesmo ano trabalhei, junto com a supervisão e orientação de um Educador Físico, como monitor de natação para bebês. Foi uma experiência muito enriquecedora, tanto por estar em contato com o desenvolvimento infantil, como estar no papel de educador. Perceber a evolução deles era de uma satisfação muito grande. Em 2008 passei seis meses como ajudante da comissão técnica de um clube, dentro do departamento de futebol. Acompanhava os treinos os jovens atletas, de 7 a 18 anos, nas diferentes categorias. Em 2009 fiz a disciplina Introdução a Psicologia Desportiva, que faz parte do quadro de disciplinas optativas da Faculdade de Educação Física da UnB. Participei de algumas palestras e até fiz uma viagem para ver o grupo de psicólogos que atuam no time de futebol Corinthians, em São Paulo. Ao longo desse semestre foi que tive o meu interesse despertado profundamente para me envolver com a psicologia do esporte. Em 2010, aproveitando um período de greve na Universidade de Brasília, realizei um intercâmbio de seis meses em Los Angeles, Califórnia, onde trabalhei em uma academia.

Formei em Psicologia em 2012. Passei o ano de 2013 fazendo atendimentos clínicos e trabalho voluntário no Centro de Atendimento Especializado em Psicologia da UnB e no Centro Médico do Idoso do Hospital Universitário da UnB. Em 2014 entrei no mestrado no Programa de Pós Graduação em Desenvolvimento Humano e Saúde do Instituto de Psicologia da UnB.

Hoje sou graduado em Psicologia, com habilitação de psicólogo clínico e em licenciatura, e formado em Direito. 


\section{Resumo}

A psicologia do esporte e do exercício não é uma área recente, apesar de ainda ser desconhecida por muitos. Seus estudos começaram em países como Os Estados Unidos e Itália há mais de 100 anos, chegando aos seus primeiros passos no Brasil na década de 60. Os conhecimentos advindos da Psicologia e são aplicados aos praticantes de atividades físicas, no contexto esportivo em geral. O psicólogo brasileiro está dando seus primeiros passos no processo de formação como psicólogo do esporte e do exercício. O curso de Psicologia e sua proposta generalista possibilita uma divulgação amplificada das possibilidades de atuação do profissional. Na Universidade de Brasília, especificamente, as propostas do Plano de Diretrizes Curriculares em Psicologia de 2011 são encontradas no Projeto Pedagógico do Instituto de Psicologia. O presente estudo buscou verificar como acontece o processo de tornar-se psicólogo do esporte e do exercício. Utilizou-se dos conceitos de Rogers e da psicologia histórico cultural para respaldar a compreensão de como tem se dado esse processo no campo de atuação do psicólogo. Foram entrevistados três psicólogos do esporte e do exercício que se formaram na UnB e que atualmente trabalham na área. Os resultados obtidos demostraram a importância de se ter além da formação em Psicologia, uma busca de uma educação continuada após a graduação. Evidencia-se como as atividades profissionais possibilitaram uma identificação com essa especialidade. O processo de tornar-se psicólogo do esporte e do exercício passa por diferentes etapas até chegar a uma auto percepção e conscientização de que o profissional é quem ele se preparou para ser.

Palavras chave: psicologia do esporte, formação em psicologia, tornar-se psicólogo. 


\begin{abstract}
Sports and exercise Psychology is not a recent area, although it is still unknown to many people. Studies on the subject began in countries like the United States and Italy more than 100 years ago, reaching its first steps in Brazil in the 60's. Researches in the area involve knowledges derived from Psychology and are applied to practitioners of physical activity in the general sport's context. Brazilian psychologists are taking their first steps in the formation process towards becoming sports and exercise psychologists. The psychology course and its general proposal enables an amplified dissemination of the professional's possible fields of work. At the University of Brasilia, specifically, the proposals of the Psychology Curriculum Guidelines Plan of 2011 are found in the Pedagogic Project of the Psychology Institute. The present study aimed to verify how the process of becoming a sports and exercise psychologist happens. Concepts from Rogers, and historic and cultural psychology were used to support the understanding of how this process finds itself in the psychologist's field. Three sports and exercise psychologists that graduated from UnB and currently work in the field were interviewed. The results obtained showed the importance of having in addition to a Psychology formation, a search for a continued education after graduation. It is evident how professional activities allow an identification with this specialty. The process of becoming a sports and exercise psychologist runs through various steps until a self-perception and an awareness is reached: that this professional is who he prepared to be.
\end{abstract}

Key words: sports psychology, formation in psychology, becoming a psychologist. 
SUMÁRIO

AGRADECIMENTOS …......................................................................................

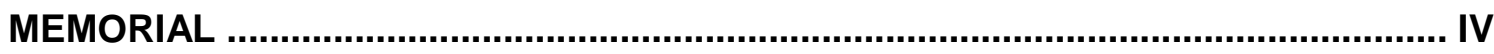

RESUMO (......................................................................................................... V

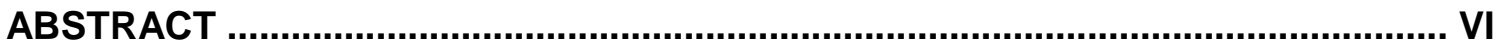

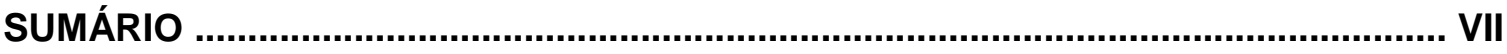

I - INTRODUÇÃO ........................................................................................... 1

II - FUNDAMENTAÇÃO TEÓRICA .................................................................... 4

Capítulo 1 - A PSICOLOGIA DO ESPORTE .................................................. 4

1. 1. A psicologia do esporte e do exercício ........................................................ 4

1. 2. O início da psicologia do esporte ........................................................ 9

1. 3. Início e desenvolvimento da psicologia do esporte no Brasil ................... 12

1. 4. Tendências e necessidades da Psicologia e do psicólogo do esporte.... 15

Capítulo 2 - FORMAÇÃO DO PSICÓLOGO DO ESPORTE ..................................... 22

2. 1. A formação em Psicologia no Brasil ......................................................... 22

2. 2. Projeto Pedagógico do Curso de Graduação em Psicologia do Instituto de Psicologia da Universidade de Brasília (PPC IP/UnB) ............................................ 28

2. 3. O Instituto de Psicologia da Universidade de Brasília .............................. 30

2. 4. O especialista em Psicologia no Brasil ........................................................... 36

2. 5. A Expansão da Psicologia do Esporte e do Exercício no Brasil ............... 39

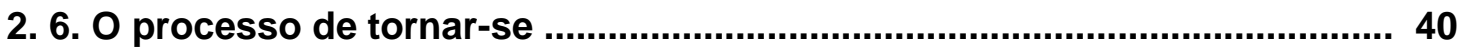

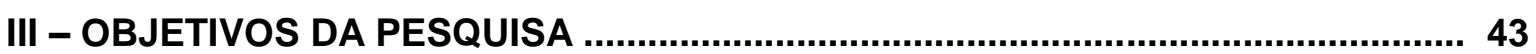

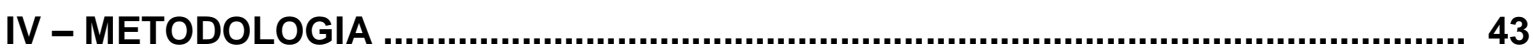




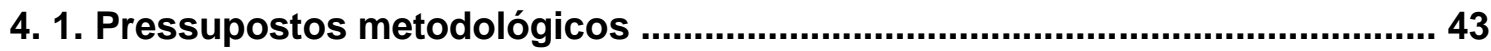

4. 2. Contexto da pesquisa e participantes .................................................... 45

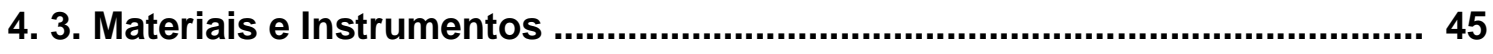

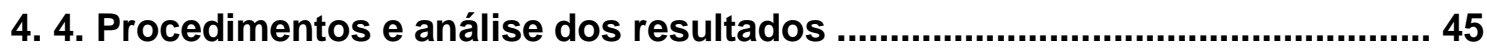

V - RESULTADOS E DISCUSSÕES ................................................................... 46

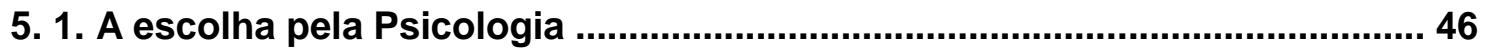

5. 2. O interesse pela psicologia do esporte e do exercício .............................. 46

5. 3. Tornar-se psicólogo do esporte no curso de Psicologia da UnB ................. 47

5. 4. Tendências da psicologia do esporte e do exercício .................................. 52

5. 5. Especialização em psicologia do esporte e do exercício ............................. 54

5. 6. Sugestões para 0 avanço da área ................................................................ 56

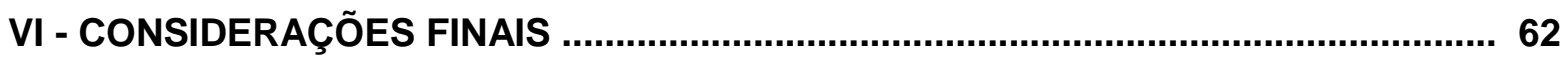

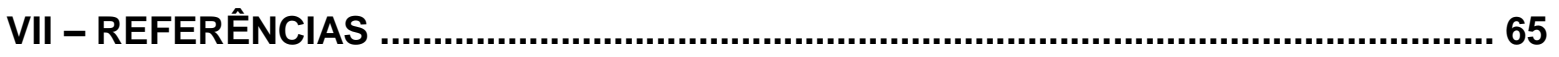

ANEXO A - Roteiro de entrevista semiestruturada com os psicólogos .................... 70 


\section{INTRODUÇÃO}

A psicologia do esporte e do exercício é uma área que vem ganhando espaço nos últimos anos. Em 1985 foi reconhecida como um campo da Psicologia e teve sua disciplina específica sendo ofertada pelas primeiras vezes em algumas universidades brasileiras no final da década de 90. Em 2007 foi reconhecida pelo Conselho Federal de Psicologia como especialidade do psicólogo. Seus estudos não estão restritos ao curso de graduação em Psicologia, mas em outras áreas como educação física, medicina, sociologia e nutrição que também se utilizam dos conhecimentos advindos de suas pesquisas. Atualmente é vista em diferentes contextos, tais como: escola, hospitais, academias, centros de treinamento das mais diversas modalidades esportivas, entre atletas iniciantes, amadores e atletas de ponta, profissionais e que buscam o alto rendimento.

Ao definirmos a psicologia do esporte e do exercício, encontramos uma ciência que busca compreender pessoas e seus comportamentos em contextos os quais são realizadas práticas esportivas, e como aplicar de maneira prática as descobertas desses conhecimentos. Portanto, a partir dessa definição, podemos dizer que esse campo da psicologia procura compreender quais são as influências do esporte no indivíduo na tentativa de auxiliar e fazer com que este possa se aperfeiçoar e se utilizar de todos os benefícios dessa prática.

O desenvolvimento da área está muito ligado em como se dão as relações pessoais, interpessoais e profissionais das pessoas que estão presentes no contexto das atividades físicas. O psicólogo do esporte, ao exercer suas atividades, constitui-se a partir dos ensinamentos de sua formação em psicologia, assim como nos elementos culturais de onde estão sendo realizadas as atividades e dos conhecimentos específicos do exercício físico e do esporte. Dessa forma, o psicólogo esportivo deve trabalhar com atenção e rigor científico na prática esportiva para não convertê-la em uma Psicologia que simplifica os fenômenos do esporte.

Os primeiros estudos da psicologia do esporte e do exercício foram realizados no final do século XIX nos Estados Unidos. A princípio, os psicólogos tentavam verificar o porquê de determinadas variáveis psicológicas influenciarem no rendimento de atletas de alto desempenho. Com o passar dos anos foi-se tendo novas percepções de como a psicologia poderia ser utilizada no contexto esportivo. Surgiu o interesse de se trabalhar com praticantes de atividades físicas em geral, além dos atletas de elite, como amadores, praticantes de atividades de lazer e recreacional, em processo de reabilitação, na área escolar e no desenvolvimento, entre outras. 
O início da psicologia do esporte no Brasil se deu na década de 60. Os primeiros estudos estavam mais voltados para as áreas de motivação e estresse, que ainda são dois tópicos bastante estudados atualmente, e principalmente com jogadores de futebol. O que pode ser explicado tanto pela cultura desse esporte no Brasil, como a conquista da copa do mundo de 1958.

A psicologia do esporte nas últimas décadas vem tendo o seu maior desenvolvimento na história, tanto no Brasil como em outros países. Os gastos com estudos relacionados aos esportes nunca foram tão grandes. Isso incentiva as pesquisas e abre espaços para a construção de novas teorias. O esporte, e principalmente o de alto rendimento, atinge um número muito grande de pessoas diariamente e está sempre presente nas notícias de destaque da mídia.

A tendência é que a área continue em ascensão, com estudos feitos em diversos países e com variadas modalidades e que busque alcançar cada vez mais a importância social do desenvolvimento da psicologia do esporte e do exercício. Devemos desempenhar sempre um trabalho profissional e de qualidade, estando atento às subjetividades dos indivíduos que estão sendo atendidos pelos psicólogos do esporte.

A formação em psicologia no Brasil segue os parâmetros das Diretrizes Curriculares Nacionais em Psicologia, documento formulado após anos de debates e reflexões e que teve sua promulgação em 2011. Nele são estabelecidas as cargas horárias do curso, como se dão os projetos de pesquisa, extensão, estágios, e priorizam a formação generalista do curso. Cada universidade tem a possibilidade de adequar e moldar seu currículo, mas respeitando os limites impostos pelas DCN.

A formação em psicologia na UnB teve significativas mudanças nos últimos anos, após a apresentação do novo currículo conforme as DCN. O curso tem a proposta de ser realizado em cinco anos, e o aluno deve cumprir um número mínimo de créditos em disciplinas obrigatórias. Além destas, existe uma grande diversidade de escolhas entre outras disciplinas chamadas optativas, as quais o aluno irá dar a ênfase que julgar ser mais atrativa para a sua formação. Por último, existem as disciplinas de módulo livre, as quais o aluno tem a possibilidade de estudar matérias de outros cursos, estas possuem um número máximo para ser contabilizado na hora de se completar a carga horária do curso de psicologia. Além desses créditos, o aluno deve ter no mínimo $15 \%$ da carga horária do curso para a realização de estágios que são oferecidos pela própria UnB em diferentes áreas.

O aluno de psicologia que deseje se aprofundar na área da psicologia do esporte e do exercício tem a possibilidade de cursar a disciplina específica que é ofertada desde o ano de 2008. Além disso, existe a possibilidade de fazer pesquisa e estágio caso o aluno tenha interesse. Por se tratar de uma área que está há pouco tempo nos currículos das 
universidades brasileiras, e há apenas oito anos na UnB, alguns profissionais que atuam no campo não tiveram a oportunidade de adquirir seus conhecimentos durante a graduação. $O$ objetivo deste estudo é, portanto compreender como se dá o processo de tornar-se psicólogo do esporte.

A metodologia qualitativa se adequou melhor para que os objetivos pretendidos fossem alcançados. Para a compreensão de como se deu o processo de tornar-se, usamos a teoria rogeriana para guiar nossos estudos, juntamente com o respaldo da psicologia histórico cultural para perceber como se deram esses momentos de formação para os psicólogos do esporte. Sendo assim, foram feitas três entrevistas semi estruturadas com três psicólogos do esporte, individualmente, que atuam na área e que se formaram na UnB. Esse contato possibilitou um diálogo aberto entre entrevistador e entrevistado, onde novos questionamentos e respostas surgiram e que foram incentivados para compreender de maneira mais abrangente os objetivos desta pesquisa.

Os resultados foram separados em tópicos, por aglomeração de características similares sobre determinados assuntos. Os entrevistados contaram os motivos da escolha do curso de graduação em psicologia, como foi esse período, os primeiros contatos e interesses pela psicologia do esporte e do exercício, suas formas de estudo, capacitação, demandas, sugestões, e o que fizeram após a graduação para chegar onde estão atualmente.

Por fim, podemos dizer que os objetivos propostos estudados foram atendidos de maneira satisfatória, e espera-se que os questionamentos que surgiram possam incentivar novos estudos. 


\section{FUNDAMENTAÇÃO TEÓRICA}

\section{Capítulo 1 - A PSICOLOGIA DO ESPORTE}

\section{A psicologia do esporte e do exercício}

Encontrarmos frequentemente nos meios de comunicação e de publicidade que a prática esportiva pode trazer muitos benefícios para os seus praticantes. Esses benefícios seriam dos mais variados, desde o aumento da autoestima e da melhoria da qualidade de vida até o controle de doenças crônicas ou ligadas ao sedentarismo. A cultura do esporte é consumida, praticada, vendida e apreciada por bilhões de pessoas (Galatti, 2010). E esse consumo, entre outras atividades, influencia no avanço da ciência esportiva e dos campos que a estudam. Porém, deve-se estar atento quanto a como ocorrem esses avanços.

A psicologia do esporte e do exercício, enquanto campo da ciência vem crescendo e ampliando suas áreas de atuação nos últimos anos. Já é vista em diferentes contextos, tais como: escola, hospitais, academias, centros de treinamento das mais diversas modalidades esportivas, entre atletas iniciantes, amadores e atletas de ponta, profissionais e que buscam o alto rendimento. Diferentes profissionais, além do psicólogo, estão estudando afundo a psicologia esportiva. Esses contemplam variadas áreas, como saúde, tecnologia, ciências sociais, e abrangem as mais diversas faixas etárias dos praticantes de atividade física (Marques, 2003).

Segundo o entendimento clássico de Caspersen (1985), a atividade física pode ser definida como qualquer movimento realizado pelo corpo cujo gasto calórico seja superior em comparação ao indivíduo em repouso. O exercício físico, por outro lado, é considerado uma atividade física, mas estruturado e realizado de forma repetitiva. Por último, temos o conceito de esporte como sendo "uma atividade competitiva institucionalizada que envolve esforço físico vigoroso ou o uso de habilidades motoras relativamente complexas, por indivíduos, cuja participação é motivada por uma combinação de fatores intrínsecos e extrínsecos" Barbanti (2006, p. 54).

Segundo Gill (2000), a psicologia do esporte e do exercício se caracterizaria como uma ciência que busca compreender pessoas e seus comportamentos em contextos os quais são realizadas práticas esportivas, e como isso aplicar de maneira prática as descobertas desses conhecimentos. Portanto, a partir dessa definição, esse campo da psicologia procura compreender quais são as influências do esporte no indivíduo na tentativa de auxiliar e fazer com que este possa se aperfeiçoar e se utilizar de todos os 
benefícios dessa prática. $O$ entendimento de como o indivíduo se desenvolve psicologicamente no âmbito das atividades físicas é de importante finalidade para a psicologia do esporte (Gill apud Weinberg \& Gould, 2008).

É necessário fazer uma diferenciação entre os contextos esportivos e dos exercícios, que englobariam atividades físicas em geral. A psicologia do esporte e do exercício não se restringe a estudos de comportamentos, mas tem também o foco nas pessoas, na sua integralidade, dando possibilidades distintas de intervenção e aplicação de diferentes abordagens teóricas psicológicas (Gill, 2000). Com uma noção um pouco mais ampla do conceito de psicologia do esporte e do exercício, e já pontuando algumas características dos profissionais da área, descrevem Pesca e Cruz (2011, p.11):

A psicologia do esporte é o estudo científico das pessoas e seus comportamentos no contexto esportivo e de exercício, bem como as aplicações práticas derivadas dos conhecimentos gerados por esses estudos. Nesse sentido, a Psicologia do Esporte é, ao mesmo tempo, uma ciência aplicada e um campo de intervenção dos psicólogos, cujas competências podem auxiliar na compreensão dos processos psicológicos instalados ou geridos no âmbito da atividade esportiva em geral. Cabe ao psicólogo especialista nesta área desenvolver e operar conhecimentos e métodos, visando compreender em que medida a participação em esportes afeta 0 desenvolvimento psicológico, a saúde e o bem-estar dos atletas.

A partir do ponto de vista desses autores, vale destacar que a psicologia do esporte e do exercício pode ser compreendida não só como uma ciência aplicada, mas também como um campo de intervenção. Isso amplia a sua forma de estudar e auxilia na compreensão dos processos psicológicos que se desenvolvem nesse contexto. Podemos ver também que é interessante ao psicólogo do esporte possuir conhecimentos pertinentes ao tipo de trabalho desenvolvido, e, que, apesar de apresentar genericamente todo o esboço da psicologia para guiar o seu trabalho, deve ter consciência que é um campo que possui peculiaridades. Nessa gama de possibilidades, Katia Rubio (1999, p. 68) coloca que "o reflexo disso é que, como psicóloga do esporte, aprendi ser imprescindível adentrar nesse mundo, conhecendo as modalidades, o fenômeno e as instituições esportivas para poder pensar numa prática".

Ao ser conceituada por Feltz (1992), essa especialidade é identificada como uma subdisciplina da Psicologia, enquanto outros autores a consideram como uma subdisciplina das Ciências do Esporte (Gill,1986). Esperamos que essa divergência quanto à identificação do que seria e onde deveria estar a psicologia do esporte venha promover 
mais reflexões e espaços para debates solidários e que ajudem a desenvolver os estudos da área como um todo. O papel da formulação da disciplina em conjunto com os profissionais de diferentes ramos da ciência só tem, ou deveria ter, a acrescentar a evolução dos conhecimentos. Vão ser mencionados posteriormente os esperados efeitos positivos ao se tratar a psicologia do esporte e do exercício como uma ciência interdisciplinar.

Apesar de já se ter, ao longo do processo de construção da área, uma ideia mais abrangente sobre as suas finalidades, atualmente ainda existem estudos psicológicos tratados nessa ciência que visam apenas o alto rendimento dos atletas. A psicologia do esporte e do exercício busca contribuir com a otimização dos desempenhos atléticos do sujeito ao menos em quatro competências básicas para a prática de alto nível: Competência Física, Técnica, Táticas e Emocionais (Peixoto, 2012).

Com uma perspectiva um pouco diferenciada, existe o entendimento de Jordão (2006), que coloca a psicologia do esporte como uma área da psicologia que visa promover a saúde, a comunicação, as relações interpessoais, a liderança e a melhora do desempenho esportivo. Com um conceito amplo como esse, podemos inferir que existem inúmeras maneiras de se trabalhar nesse campo. Ao se colocar como uma área da psicologia, esta deve ser entendida como partindo de estudos psicológicos, mas, não necessariamente sendo feita apenas por psicólogos.

Com a leitura dos conceitos já expostos, destacamos a afirmação de Jordão (2006) quando traz de maneira diferenciada a necessidade de se explorar a comunicação e as relações interpessoais na prática da psicologia do esporte. Isso é pertinente no processo dos estudos psicológicos em geral. Um olhar para o indivíduo como um todo, que também é praticante de atividade física.

No mundo contemporâneo onde as relações sociais e financeiras se encontram muitas vezes de maneira tão acirradas e competitivas, além da necessidade de alto desempenho e rendimento, características comuns do modo de produção capitalista, a psicologia do esporte e do exercício também é influenciada a reproduzir esses aspectos (Silva, 2007). Dessa forma, é esperado do psicólogo esportivo estar consciente quanto ao seu papel pessoal, profissional e também como cidadão. A utilização dos pressupostos éticos e morais, e a busca de reflexões das ações empregadas necessitam ser constantes no modo de atuação de acordo com sua visão de mundo.

Pela concepção apresentada por Singer (1993), a psicologia do esporte e do exercício integra a investigação, a consultoria clínica, a educação e atividades práticas sucessivas, articuladas e associadas à compreensão, à explicação e à influência de comportamentos de indivíduos e de grupos que estejam envolvidos em esporte de alta competição, esporte recreativo, exercício e outras atividades físicas. Mesmo que o ponto de 
vista tenha sido apresentado há duas décadas, ele é relevante por apresentar o âmbito da educação e por verificar as possibilidades de estudos e compreensões em grupos. Nesse sentido, pode-se ter uma investigação ainda mais completa da área.

Dois autores que contribuem bastante para o avanço da ciência psicológica esportiva são Weinberg e Gould. Para eles (2001, p. 28), "a Psicologia do Esporte e do Exercício é um estudo científico de pessoas e seus comportamentos em atividades esportivas e atividades físicas, e a aplicação deste conhecimento". Com essa definição conceitual, não se limitam os aspectos de áreas ou abordagens. Isso de certa forma estimula a se utilizar de diferentes ferramentas para os estudos, e não deixa de demonstrar a necessidade de se aprofundar esses conhecimentos por meio de estudos científicos. Talvez, por tratar de maneira tão genérica, e deixando abertas as possibilidades de se compreender a psicologia do esporte, esse conceito é tão utilizado no meio acadêmico.

As definições apresentadas são essenciais para entender que a psicologia do esporte e do exercício, além de ser uma disciplina acadêmico-científica, é também um campo de intervenção profissional que envolve conceitos da Psicologia e das Ciências do Esporte. Enquanto campo de intervenção profissional refere-se à prática da Psicologia por profissionais que se especializaram no trabalho com atletas ou praticantes de exercícios físicos em diversos contextos.

Nesse ambiente, percebe-se a psicologia do esporte e do exercício como ramo da Psicologia, das Ciências do Esporte e do próprio esporte, sendo simultaneamente um campo profissional que olha para o esporte e para o exercício físico na perspectiva psicológica. Uma imagem interessante que pode exemplificar o mencionado é encontrada no texto de Vieira \& Cols (2010).

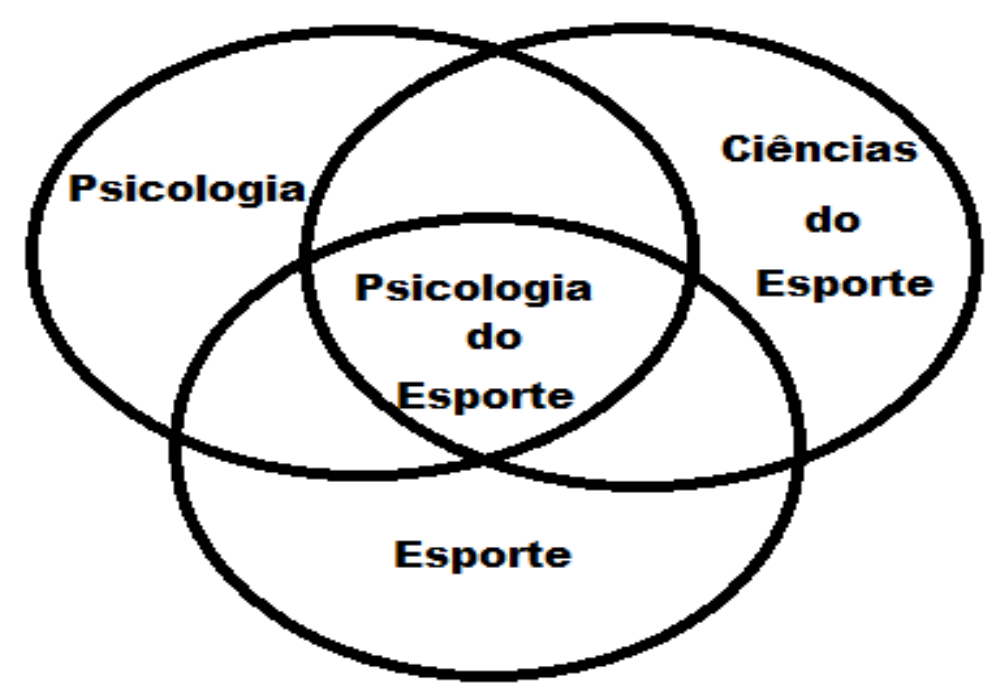

A psicologia do esporte e do exercício desenvolve-se também nas relações interpessoais e profissionais. O profissional que atua nessa área, ao adquirir uma formação de conhecimentos que foram garantidos e advindos de uma formação em Psicologia, 
fortalece-se juntamente ao agregar os conhecimentos específicos do exercício físico e do esporte. Tornando-se imprescindível para esse profissional mergulhar na cultura e nos elementos constituintes desse contexto específico de atuação. Dessa forma, o psicólogo esportivo deve trabalhar com atenção e rigor científico na prática esportiva para não convertê-la em uma Psicologia que simplifica os fenômenos do esporte.

Samulski (1992) separa em quatro grandes campos os quais a psicologia do esporte poderia ser caracterizada e suas aplicações. Entretanto, ele deixa claro que pode haver outras áreas para atuação dos profissionais, seja pesquisador ou alguém que intervém mais diretamente. Os campos são:

1- O esporte de rendimento: que busca promover as maiores positividades do desempenho numa estrutura formal e institucionalizada. A partir dessa institucionalização, o psicólogo atua analisando e transformando os determinantes psíquicos que interferem no rendimento do atleta e/ou grupo esportivo.

2- O esporte recreativo: que visa o bem estar e aumento de qualidade de vida para todas as pessoas. É praticado de maneira voluntária e com conexões com os movimentos de educação permanente e com a saúde. O psicólogo, nesse caso, atua na primeira linha de análise do comportamento recreativo de diferentes faixas etárias, classes sócias econômicas e atuações profissionais em relação a diversos motivos, interesses e atitudes.

3- O esporte escolar: que tem por objetivo a formação, norteada por princípios socioeducativos, preparando seus praticantes para a cidadania e para o lazer. Nesse caso, o psicólogo busca compreender e analisar os processos de ensino, educação e socialização inerentes ao esporte e seu reflexo no processo de formação e desenvolvimento da criança, jovem ou adulto praticante.

4- O esporte de reabilitação: que desenvolve atividades voltadas à prevenção e à intervenção com pessoas que são portadoras de alguma necessidade especial, em razão de algum tipo de lesão decorrente da prática esportiva, ou não, e também com deficientes físicos e mentais.

É interessante que os psicólogos do esporte tenham, segundo Rubio (2000), conhecimentos específicos da psicologia e do campo em que atuam. Além disso, é importante uma diversidade nos seus estudos, e que estes englobem questões relacionadas ao meio no qual o atleta está inserido e na modalidade que pratica. É esperado que esse profissional tenha conhecimentos advindos de uma formação geral em Psicologia e que esteja sempre tentando se aprofundar nas reflexões acerca do esporte e do exercício. Quando nos referimos ao esporte, não nos restringimos apenas aos exercícios com regras e regulamentações, mas também aos diferentes tipos de atividades físicas, além de todas as características intrínsecas que cada uma possui. O entendimento 
específico do contexto de atuação e a aplicação dos conhecimentos científicos da psicologia na prática esportiva são relevantes para a atuação do psicólogo no esporte.

A psicologia do esporte e do exercício apresenta diferentes conceitos. Apesar de haver pontos semelhantes nos conceitos apresentados, não existe um conceito geral ou que satisfaça todos os parâmetros dos autores citados. Por outro lado, uma divergência conceitual não implica necessariamente em algo negativo, pelo contrário, demonstra que muito ainda se tem para crescer, desenvolver e aprimorar nesse tema. Muito pode ser compartilhado nas divergências e que pode trazer avanços científicos. A psicologia do esporte e do exercício ainda tem muito a crescer.

\section{O início da psicologia do esporte}

Os estudos relacionados à psicologia do esporte e do exercício não são recentes. As pesquisas sobre o tema remontam ao final do século XIX na América do Norte, nos Estados Unidos especificamente. Um artigo que pode ser considerado como o precursor dessa área é o de Norman Triplett, psicólogo da universidade de Indiana, EUA. Seu trabalho efetuado em 1898 buscou verificar e compreender porque ciclistas pedalavam mais rápido quando estavam em grupos ou pedalando em pares do que quando a atividade era praticada individualmente (Triplett, 1898).

Entre os estudos iniciais em psicologia do esporte, encontra-se também o de Fitz (1897), que afirmou que a prática esportiva (jogar) era um meio de se preparar para a vida. Essa prática promoveria uma melhora na capacidade de julgamento, na habilidade de perceber melhor as mudanças de situações cotidianas, e na habilidade de reagir mais rapidamente ao dinamismo do ambiente contemporâneo. A importância da prática esportiva é destacada nos estudos de Patrick (1903) e de Hermann (1921), que pontuam o esporte como algo que permite mudanças nos hábitos de vida e que os músculos são os mecanismos pelos quais se desenvolvem a imitação, a obediência e o caráter. Esses autores relatam que seria por meio do esporte que a mente, o corpo e a alma se manifestariam em situações reais.

Já na década de 20 do século passado, surge uma nova geração de estudos relacionados à psicologia do esporte. O grande nome da época é Coleman Griffith, e por muitos é considerado o pai da psicologia do esporte americana (Kroll e Lewis, 1970). O primeiro laboratório específico da área foi criado por Griffith. O foco dos seus trabalhos e das suas publicações era o estudo da participação da psicologia para a melhoria do desempenho de atletas de alto rendimento (Weinberg, 2008). A psicologia do esporte era bastante ligada à educação física nesse período. 
A Educação Física não é só composta pelos estudos fisiológicos pertinentes às práticas esportivas, mas tem em sua base todo um entendimento que se deve focar no indivíduo como um todo, e nesse sentido se aproxima consideravelmente da Psicologia do esporte e do exercício. Portanto, os profissionais dessas áreas podem e devem ter trocas de informações, com entendimentos subjetivos que foquem no indivíduo e que levem em consideração as suas relações sociais nos âmbitos os quais eles interagem (Rubio, 2001).

Foi presenciada na década de 60 uma separação da psicologia do esporte com a educação física. Os psicólogos aqui começaram a compreender fatores psicológicos e como estes poderiam influenciar no desempenho da prática esportiva e motora dos praticantes de atividades físicas. Nesse âmbito, era pretendido alcançar um melhor entendimento de como a participação em esportes e na educação física influenciava o desenvolvimento psicológico (Weinberg, 2008).

Após a Segunda Guerra Mundial, entre os anos de 1945 e 1964, surgiram vários laboratórios de psicologia do esporte nos Estados Unidos, tais como os de Franklin Henry (Universidade de Berkeley), John Lawther (Universidade da Pensilvânia) e Arthur SlaterHammer (Universidade de Indiana), os quais começaram a oferecer cursos de Psicologia do Esporte nas suas universidades. Também Bruce Ogilvie e Thomas Tutko lançam nesse mesmo período, no ano de 1966, o livro Problem Athletes and How to Handle Them. Esse livro foi muito popular entre os técnicos esportivos e atletas, e devido a ele Ogilvie foi referenciado como o Pai da Psicologia Aplicada ao Esporte (Cox, Qiu \& Liu, 1993). Nesse período, a corrente teórica de influência de estudos na psicologia era o Behaviorismo de Watson.

No Primeiro Congresso Mundial de Psicologia do Esporte, realizado na cidade de Roma em 1965 verificou-se uma grande dispersão conceitual e metodológica no que diz respeito à importância do contexto social. No Segundo Congresso Mundial, realizado nos EUA em 1969, as dimensões sociais do esporte foram abordadas por profissionais de diversas áreas, como médicos e psicólogos. Porém, já no terceiro, realizado em Madri em 1973, percebeu-se o aparecimento de um grande número de profissionais da educação física interessados no tema. A partir de 1987, além da ênfase no esporte, iniciou-se a preocupação com a Psicologia do Exercício, voltada à saúde (Araújo, 2002).

$\mathrm{Na}$ década seguinte (1966-1976), pós-congresso, reorientou-se para a aplicação, ao contexto desportivo, dos modelos e teorias da psicologia social. O paradigma de investigação era fundamentalmente experimental e laboratorial, pondo a ênfase no controle da situação. As preocupações temáticas centravam-se nas questões relacionadas com a motivação para o sucesso, nas relações entre os níveis de ativação e stress, no desempenho ou rendimento psicomotor e nos processos de facilitação social e no reforço (Feltz, 1992). 
Um fato que merece destaque na ampliação da divulgação da área foi a criação da Sociedade Internacional de Psicologia do Esporte (ISSP) no ano de 1965. Aqui se constata uma "resposta à necessidade do mercado" no desenvolvimento científico para facilitar a organização dos processos e progressos que estavam sendo verificados (Thomas, 1983. p. 07). As pessoas interessadas na área puderam tomar conhecimento da magnitude que estava se consolidando e puderam proporcionar entre si trocas de informações e o tanto que poderiam ser relevantes na emersão do campo.

Três anos após a formação da ISSP, os Estados Unidos criaram ao seu dispor a Sociedade Americana para a Psicologia do Esporte e Atividade Física. Com essa criação, houve um aumento no número de estudos com ênfase nas pesquisas básicas de rendimento, utilizando-se de práticas experimentais (Rubio, 2000).

As técnicas experimentais, que basicamente eram realizadas em laboratórios, eram consideravelmente criticadas. Havia uma escassez de instrumentos específicos para analisar o contexto desportivo, o que fazia emergir a principal crítica à época: que as pesquisas eram frágeis porque as investigações centravam-se em uma pequena dimensão de efeitos encontrados, o que comprometia os resultados, tornando-os inconsistentes. $A$ questão que se colocava no final dos anos setenta era: para que servem os fracos efeitos encontrados se não podem ser generalizados aos atletas e não conseguem explicar, e, sobretudo prever, o seu comportamento em campo? (Cox, Qiu \& Liu, 1993).

$\mathrm{Na}$ década de 80, ocorreu a passagem do enfoque essencialmente comportamental do esporte para uma concepção cognitivista, acompanhando a tendência da Psicologia como um todo. Em 1986, na American Psychological Association (APA) é formada a divisão 47 - Psicologia do esporte e do exercício, que especificava a qualificação necessária para se tornar um psicólogo esportivo nos Estados Unidos. Nesse contexto, são levadas em consideração, principalmente, a existência de duas áreas da psicologia esportiva: a educacional e a clínica. Reconhece-se assim a necessidade de especialização e especificação de ambas, e que são imprescindíveis, nos Estados Unidos, as suas devidas certificações para os profissionais que desejem nelas atuar (Cox, Qiu \& Liu, 1993).

A segunda metade dos anos noventa trouxe ainda uma nova orientação metodológica para a investigação na psicologia do esporte. Nesse momento, são incentivadas metodologias qualitativas e a utilização de técnicas mais ideográficas no estudo de atletas de elite, em contexto aplicado e preferencialmente de forma longitudinal, como por exemplo, o estudo de Jones \& Hardy (1990). Nessa década era forte a ênfase pela percepção da natureza, e como ela deveria ser individualizada para se compreender a resposta comportamental no contexto esportivo. Surge um interesse em conhecer o 
comportamento dos melhores atletas, para ajudar nas investigações de como favorecer o rendimento esportivo (Isberg, 1993).

Assim, são feitas propostas de se criar novos projetos de investigação transdisciplinares, sistemáticos e muitas vezes longitudinais para se conseguir construir modelos explicativos específicos para as questões de práticas que se colocam nos contextos atléticos (Gill, 1999). Esse posicionamento busca ampliar os métodos de investigação na área da Psicologia do Esporte e do Exercício para melhor se adaptar aos diferentes objetos e contextos que surgem com o tempo.

Grande parte dos estudos que observamos nesse tópico demonstra que há décadas que se estuda o tema ao redor do mundo, e não é recente o seu desenvolvimento acadêmico e científico. Tem-se o avanço da psicologia do esporte e do exercício principalmente nos Estados Unidos e na Europa, porém, aqui no Brasil também podemos notar a construção e evolução do assunto há muitos anos, como veremos a seguir.

\section{Início e desenvolvimento da psicologia do esporte no Brasil}

No Brasil, os primeiros estudos foram realizados na década de 50 , como o do Psicólogo João Carvalhaes que trabalhou com juízes da Federação Paulista de Futebol, focando nos conceitos de estresse. Também considerado um dos precursores na psicologia do esporte, Athaide Ribeiro da Silva, acompanhou a seleção brasileira de futebol em 1962, que viria a ser bicampeã da copa do mundo, no Chile. Cinco anos depois, Athaide publicou o livro Psicologia Esportiva e a Preparação do Atleta, considerado o primeiro livro escrito por um brasileiro sobre a psicologia do esporte e do exercício (Rubio, 2000).

Em 1979 foi fundada a Sociedade Brasileira de Psicologia do Esporte (SOBRAPE), que veio a ser alterada para Sociedade Brasileira de Psicologia do Esporte, Atividade Física, Recreação e Lazer (Samulski, 2000). O Brasil ocupa uma posição de liderança na América Latina, o que pode ser comprovado com base no grande volume de trabalhos publicados e no número de congressos realizados, bem como na quantidade de laboratórios de Psicologia do Esporte existentes principalmente na região sul do Brasil. Isso não significa que a área já esteja consolidada e que grandes avanços ainda não possam ser atingidos.

Após a fundação da SOBRAPE, foi instituído que depois de dois anos haveria a realização do I Congresso Brasileiro de Psicologia do Esporte. Logo, em 1981, na cidade de Porto Alegre, estiveram presentes aproximadamente mil e setecentos profissionais interessados pelo tema. Esse evento inovador e diferenciado até então, foi considerado como um marco para a área no Brasil e para a América Latina. A partir daí, alavancaram-se os estudos científicos, o que foi de grande significância para o desenvolvimento da Psicologia do Esporte (Becker, 2000). 
Posteriormente, influenciado por esse congresso, começaram a ser criadas as Sociedades Estaduais Brasileiras. Essa influência não se restringiu apenas ao Brasil, mas também aos países próximos. Quando os profissionais de determinada área se encontram, como em congressos, por exemplo, isso faz gerar uma multiplicação de conhecimentos e interações que necessariamente desenvolvem as concepções abordadas. Em termos de divulgação e difusão da psicologia do esporte e do exercício, a realização de congressos foi talvez o mais importante suporte para busca de novas informações e que proporcionou as mais amplas disponibilidades de acervo teórico para os congressistas. Foram realizados, entre 1980 e 2000, mais de trinta congressos específicos para a área, fazendo com que a Psicologia do Esporte e do Exercício estivesse mais exposta e reconhecida por outras disciplinas acadêmicas (Becker, 2000).

Embora estudada desde o final do século XIX, a psicologia do esporte e do exercício veio ganhar maior visibilidade somente nas últimas décadas. De acordo com Carvalho e Sampaio (1997), o Conselho Federal de Psicologia elaborou, em 1985, um documento para a área ser integrada ao Catálogo Brasileiro de Ocupações do Ministério do Trabalho, no qual se identificou o Psicólogo do Esporte como área de atuação.

Essa área da psicologia está inserida dentro de um campo que vem sendo denominado de Ciências do Esporte, composto por disciplinas como Antropologia, Filosofia e Sociologia do esporte. No que também se refere à área sociocultural, incluindo também a medicina, fisiologia e biomecânica do esporte, demonstrando uma tendência, e uma necessidade, à interdisciplinaridade (Rubio, 1999).

No que condiz a essas tendências, entretanto, não deveriam ser consideradas como práticas interdisciplinares, haja vista que essas diferentes subáreas atuam somandose umas as outras, e não apenas se relacionando uma com a outra. Esse estado onde as Ciências do Esporte estão se encontrando atualmente é denominado por Bracht (1995) como pluridisciplinar. Uma perspectiva interessante que remete à ideia de uma atuação coletiva sendo superior à soma das partes.

Para Peixoto (2012), são desmembrados outros temas a partir do que a psicologia do esporte pode proporcionar, como ansiedade, depressão, estresse, liderança, bem estar psicológico, pensamentos e sentimentos influenciando no alto rendimento, enfrentamento de perdas ou desilusões, motivação, personalidade, entre outros. Dessa maneira, vêm sendo requisitados diferentes profissionais, com conhecimentos variados para promover um trabalho que vai além do treinamento específico de determinada modalidade, a fim de conseguir melhores resultados no campo da competição esportiva.

Considerando alguns dos pontos já apresentados, podemos dizer que a psicologia do esporte e do exercício consiste na realização de práticas sistemáticas para uma construção de conhecimento dentro da psicologia e no meio das atividades físicas. $O$ 
Psicólogo que atua nessa área pode se formar de diversas maneiras, entre elas, ao realizar pesquisas, estudos, e participar práticas ou experiências.

Nesse sentido, a Association for the Advancement of Applied Sport Psychology (AAASP) estabeleceu como princípios gerais e diretrizes éticas para os profissionais que atuam com a Psicologia do Esporte: competência, integridade, responsabilidade pessoal e científica, respeito pelos direitos e pela dignidade das pessoas, preocupação com o bemestar dos outros e responsabilidade social (Weinberg e Gould, 2001). O emprego desses princípios deve ser respeitado pelos atletas de alto rendimento, mas não somente por esses, mas por todos os praticantes de atividades físicas, e por todos os profissionais que atuam no campo, sobretudo o psicólogo esportivo, um profissional ainda pouco inserido no cenário esportivo competitivo do Brasil (Rubio, 2007).

A prática profissional pode ser uma grande ferramenta para se adquirir informações em determinados contextos, e no da psicologia do esporte e do exercício não é diferente. Os princípios morais na construção dos pressupostos éticos são necessários ao se trabalhar com pessoas, sendo por isso dada tamanha relevância para a AAASP sobre como os profissionais devem estar amparados. O conhecimento sendo, portanto, algo que pode ser conquistado de diversas formas, não é estático e é interessante que venha sempre se aprimorando.

Martens (1987) afirmou que seria possível ver profissionais trabalhando com a Psicologia do Esporte e do Exercício em dois campos distintos de atuação: no primeiro deles estaria a Psicologia do Esporte acadêmica, cujo interesse profissional recairia sobre a pesquisa e conhecimento da disciplina psicologia do esporte; no segundo estaria a psicologia do esporte aplicada diretamente com os praticantes de atividades físicas no contexto do exercício.

Além das questões acadêmicas envolvidas nesses dois campos, essa divisão reflete a preparação e as possibilidades de atuação dos profissionais junto ao seu campo específico, que se, por um lado representa certo corporativismo, por outro indica a abertura de uma nova oportunidade (Martens, 1987). Na prática podem ser observadas como essas duas áreas se separam, porém, a tendência no contexto atual é a união desses "distintos campos", talvez não tão distintos assim, sendo contemplados por psicólogos do esporte.

A psicologia do esporte e do exercício vem caminhando a passos largos nas últimas décadas no mundo. Muito se tem feito para o desenvolvimento da área. Esses avanços mostram-nos que ainda se tem um longo caminho pela frente a ser explorado. Deve-se estar aberto para verificar novas possibilidades e a todo tempo construir novas informações. Com isso, a sociedade como um todo só tem a ganhar. 


\section{Tendências e necessidades da Psicologia e do psicólogo do esporte}

Além da psicologia do esporte e do exercício ser considerada uma área recente e emergente na Psicologia em geral, e ainda tendo tantas divergências em relação aos seus conceitos, competências, formas de atuação e intervenção, principalmente nas últimas décadas percebe-se seu maior crescimento. A Psicologia como um todo, em suas linhas, abordagens, campos, não apresenta um consenso desde os seus primeiros passos, porém, isso não significa que haja certo ou errado, mas sim que os psicólogos apresentam pontos de vista diferentes, e isso tem sido bastante enriquecedor para as reflexões e desenvolvimento da ciência psicológica.

Algumas abordagens teóricas começam a ganhar destaque e notoriedade na psicologia do esporte e do exercício. Segundo Weinberg e Gould (2008), as principais são: 1 - Psicofisiológica - estudo do comportamento por meio de seus processos psicofisiológicos subjacentes que ocorrem no cérebro e suas influências na atividade física. Tem como objetivo compreender a relação entre cérebro e corpo. Com essa abordagem, verifica-se uma tentativa de se abranger conceitos comportamentais, fisiológicos e neurológicos para que a finalidade da psicologia do esporte e do exercício seja atingida.

2 - Sociopsicológica - estudo de como o comportamento é determinado por uma interação complexa entre o ambiente e a constituição pessoal do atleta ou do praticante de exercício. A partir dessa perspectiva, é levada em consideração uma ideia mais ampla, que, além de analisar o sujeito, abrange-se o ambiente no qual este está inserido. Além dos aspectos pessoais e subjetivos, avalia-se como o contexto social no qual o praticante da atividade física se insere.

3 - Cognitivo-comportamental - pressupõe que o comportamento é determinado tanto pelo ambiente como pela cognição e que os pensamentos e as interpretações desempenham um papel especialmente importante no comportamento dos atletas e praticantes de exercício. Utilizam-se do auto-relato para avaliar autoconfiança, ansiedade e motivação intrínseca.

4 - Emoção e Subjetividade - pressupõe o atleta e o praticante de exercício como sujeito das emoções. Portanto, é a partir da manutenção dessas emoções e da intervenção psicológica, dentro ou fora do contexto do exercício, que o psicólogo desenvolve os conceitos da psicologia do esporte.

Devemos deixar claro que o ponto citado acima feito por Weinberg e Gould (2008) nos traz um panorama geral de suas opiniões, mas que estas não limitam ou esgotam as possibilidades de se trabalhar com a Psicologia do Esporte e do Exercício tanto para os autores quanto para nós neste trabalho.

Em relação à atuação do psicólogo do esporte e do exercício, e a compreensão dos conceitos pertinentes à saúde, e às possíveis estratégias de intervenção, para Angelo 
(2003) verifica-se primeiramente a necessidade de se abranger a ideia de bem estar físico e psicológico do praticante de atividade física, além de outros aspectos. Sendo assim, o psicólogo do esporte deveria ter uma visão amplificada do sujeito. Ainda nas análises pertinentes ao estudo de Angelo (2003), deve-se buscar a compreensão dos aspectos sociais que o esporte promove além do seu desempenho. O impacto na elaboração de mecanismos psicológicos que advém com a prática esportiva e como estes podem ser utilizados na sociedade moderna, chama atenção para campos como educação e relações pessoais, por exemplo. A autora finaliza o capítulo com a constatação de que diferentes momentos históricos forneceram diferentes respostas à questão da saúde, e indaga ao leitor sobre qual seria o tipo de saúde que a atualmente nossa sociedade realmente busca alcançar.

Segundo Rubio (2000, p.17), "o esporte enquanto uma instituição social; tem se projetado como um dos grandes fenômenos deste final de século, agregando em torno de si um número cada vez maior de áreas e afins". Diante disso, não apenas as consideradas ciências da saúde, mas filosofia, política, mídia, direito, tecnologia, se interessam pelas implicações desse fenômeno.

Embasado em uma teoria social crítica, Kellner (2004) depara-se com novos desafios no mapeamento teórico do conceito de esporte. Suas análises agregam as culturas da sociedade, e expõe como elas podem conter novos cenários de dominação e de opressão por meio da prática esportiva, bem como a potencialidade para a democratização. Kellner (2004) também apresenta o conceito de "sociedade do espetáculo", desenvolvido pelo francês Guy Debord, que causa certo impacto nas teorias sociais contemporâneas, de modo que a adjetivação de espetáculo nas relações pessoais inferem certas explicações a fenômenos aparentes. Esse conceito descreve uma sociedade de mídia e consumo, organizada em função da produção de imagens. Uma de suas finalidades seria a de pacificação, entretenimento e despolitização, com o afastamento dos momentos de trabalho.

Podemos já nesse momento perceber que o avanço da psicologia do esporte vem acompanhado de tendências, necessidades e demandas. O psicólogo, independente em que área atue ou abordagem que utilize, tende a buscar uma consciência sobre suas percepções culturais, éticas e morais. O profissional buscaria estar em consonância com os objetivos que a psicologia e suas instituições estabelecem. Segundo Rubio (2007), o esporte é considerado um fenômeno social tanto macro como micro, com capacidade de desenvolver e potencializar as percepções pessoais, e auxiliadas por uma intervenção, pode ajudar a trazer ainda mais benefícios aos seus praticantes.

Por outro lado, não pode ser ignorado que se a prática esportiva pode trazer mudanças psicológicas significativas, estas podem ser positivas ou negativas. É importante 
que o psicólogo do esporte esteja ciente da existência desses fatores, a fim de que se possa atuar da melhor maneira. Existe uma necessidade de sempre se manter uma postura crítica por parte dos profissionais. Para que seja possível elaborar estratégias adequadas a cada contexto, e, portanto, realizando uma prática eficiente e moralmente bem sucedida. É de suma importância que o psicólogo do esporte tenha conhecimento sobre os fundamentos das outras ciências do esporte, tanto aos que permeiam os valores socioculturais quanto aos que visam estudar as especialidades de cada modalidade esportiva (Angelo, 2003).

O psicólogo do esporte deve criar um espaço em que o atleta possa se conhecer, descobrir como melhor pode lidar com as pressões internas e externas. Deve-se visar sempre o bem estar do indivíduo. E assim, como eventuais dificuldades podem ocorrer, como lesões, dificuldades nas relações pessoais, excessos de treinos, cansaço, deve-se criar conjuntamente no contexto esportivo supervisionado, estratégias subjetivas e objetivas para o manejo desses fatores negativos, como ansiedade e estresse, para que estes possam ser lidados da melhor maneira possível.

É necessário que se busque um equilíbrio entre desempenho, saúde, qualidade de vida, aspectos psicológicos e físicos entre os praticantes de atividade física. Fazendo uma retrospectiva dos avanços da área da psicologia do esporte e do exercício no Brasil, e também na América Latina, bem como, em um segundo momento, deliberando sobre suas propostas para os rumos que a área tende a tomar, Becker (2000) trata de quatro principais barreiras impostas ao desenvolvimento e crescimento da emergente área: formação, pesquisa, divulgação e ensino.

No texto, que se diferencia porque procura sistematizar e organizar a área, são feitas críticas pontuais aos quatro aspectos mencionados. É apontada a necessidade de um maior desenvolvimento teórico, que se inicia com o fomento de bibliotecas das universidades com livros sobre o tema, a organização de palestras e congressos. Outra crítica do autor é a falta de especialistas para poderem ministrar aulas e transmitir o conhecimento da psicologia esportiva. É destacada a conscientização de se promover espaços de reflexão para a divulgação e formação de novos profissionais, e o quanto isso é relevante no desenvolvimento profissional.

Nesse contexto, é verificado que em alguns momentos o Brasil ainda apresenta certas dificuldades para que um panorama exemplar seja atingido. Entretanto, diversos avanços significativos ocorreram nos últimos anos, como a criação da uma revista de Psicologia do Exercício \& Esporte e a regulamentação em 2007 do título de psicólogo especialista em psicologia do esporte pelo Conselho Federal de Psicologia (Rubio, 2007). Essas mudanças demonstram que melhorias estão sendo estruturadas para a ascensão da área. 
O esporte apresenta funções sociais, e estas devem ser levadas em consideração por parte dos sujeitos que atuam para a promoção da psicologia do esporte e do exercício. Os benefícios psicológicos que podem ser percebidos pelo caráter integralizador das atividades físicas podem causar mudanças significativas para a compreensão do indivíduo. A prática desportiva pode servir como uma forma de estimulação tanto como social e física, mas também emocional. A promoção de hábitos que possam ser realizados de maneira saudável pode ser instrumento para a diminuição de afetos negativos, como angústia, estresse, hipertensão, entre outros (Markunas, 2000).

Os profissionais de psicologia que buscam se especializar com a psicologia do esporte e do exercício, estão mais voltados aos esportes que são mais divulgados na mídia, e ligados ao alto rendimento, que contam com atletas de elite, e que visam basicamente resultados e possuem altos valores econômicos atribuídos. Ao entrar no estudo aprofundado sobre a essência das questões que permeiam toda área, os estudantes de psicologia passam por diversos estágios que os ajudam a compreender o aspecto social que também está presente nessa prática. É verificado que ainda existem algumas fragilidades quanto às inserções de possibilidades do psicólogo que não visem prioritariamente o alto rendimento (Silva, 2007).

Para todos que atuam com as ciências do esporte e a psicologia aplicada ao exercício, deve-se levar em consideração além do aprimoramento do desempenho que está sendo desenvolvido, os aspectos de formação e do desenvolvimento do indivíduo, da pessoa e cidadão de maneira geral. Ativamente estão ocorrendo efeitos no âmbito emocional, maturacional, pedagógico e psicossocial. Nesse entendimento, é verificado também que nesse campo de atuação já foi consolidado um nível de exigência de conhecimento específico em psicologia para uma boa intervenção. É importante ser feito um planejamento criterioso para que os objetivos sejam alcançados e se conscientizar que a descrição de quais serão esses "objetivos" não se diz pertinente apenas ao psicólogo, mas de todos os profissionais que participam do trabalho, a partir de diálogos e reflexões (Marques \& Kuroda, 2000).

Entretanto, a atividade física em geral, por ser um fenômeno de complexidade e características intrínsecas, também apresenta peculiaridades e facetas negativas, e estas podem causar danos àqueles que o praticam de forma inadequada, é o que descreve Silva e Ferreira (2011). O ponto de vista desses autores está na possível conversão de dependência física e psicológica de bem estar, trazer aspectos danosos de forma compulsiva, transtornos alimentares, abstinência e imagem corporal.

Ao considerar essa função social que o esporte desempenha, e como os estudiosos do tema vêm tratando essa complexidade e suas influências no indivíduo, não devemos ver esses caminhos como barreiras a serem rompidas, mas como possibilidades 
de atuação e caminhos diferenciados para se fazer um bom trabalho no âmbito da psicologia esportiva. O psicólogo como um dos profissionais que está inserido no campo das ciências do esporte, deve estar atento sempre aos conhecimentos adquiridos ao longo de sua formação, a fim de verificar e analisar quais as melhores circunstâncias a serem utilizadas no exercício de sua função.

Richardson, Faulkner, McDevitt, Skrinar, Hutchinson \& Piette (2005), indicam que o exercício físico somado a outros tipos de tratamento para pessoas com doenças mentais graves pode aliviar diversos sintomas psicológicos secundários, como baixa autoestima e auto eficácia, além do isolamento social elevado. Ainda a partir da visão destes autores, indivíduos com depressão, esquizofrenia e transtorno bipolar, por exemplo, apresentam frequentemente saúde física abaixo da média, de forma que o esporte e o exercício podem ser efetivos para a melhoria dos aspectos negativos que essas circunstâncias trazem.

Este estudo se torna pertinente para apresentar e verificar a influência psicológica que nossas atividades físicas podem desempenhar. Com isso, podemos nos tornar profissionais ainda mais capacitados e com possibilidades de trabalhos mais amplos e diferenciados, quando levamos em consideração aliar esses fatores e seus sentidos de forma entrelaçada e indivisível.

Com as diversas possibilidades que são apresentadas, principalmente advindas das diferentes abordagens psicológicas, algumas análises se identificam. Nessas, principalmente, deve-se entender que existem fortes indícios que apesar de poderem ser eficazes e relevantes, ainda podem ser mais esmiuçadas. A prática de exercícios físicos está associada a amplos conceitos de educação e saúde. A atividade física é "um processo de capacitação de pessoas, proporcionado por uma abordagem socioeducativa que assegure conhecimento, habilidades e formação da consciência crítica para tomar uma decisão pessoal com responsabilidade social" (Spinato, Monteiro e Santos, 2010, p. 258)

Os temas em pesquisas na psicologia do esporte e do exercício, que é uma ciência interdisciplinar e pluridisciplinar, são consideravelmente ditados pela prática e demanda das instituições esportivas para o desenvolvimento, principalmente, de tecnologias e rendimento. Essa vem sendo uma tendência dos estudos na área: focar no alto desempenho dos atletas profissionais. Entende-se a influência social e econômica que o esporte de elite movimenta no mundo, e seus incentivos para pesquisa, intervenção e atuação são maiores que os outros campos, como recreativo, escolar e reabilitação. Ao buscar maximizar os resultados do praticante de atividades físicas em competições, estudase amplamente o controle da concentração, incremento de habilidades de comunicação e coesão, e o manejo e enfrentamento do estresse (Rubio, 2000).

Algumas alternativas apontadas por Becker Jr (2000) para o desenvolvimento da área seriam: o aumento do fomento de pesquisas pertinentes ao tema, criação de mais 
revistas especializadas em Psicologia do Exercício \& Esporte, ampliar a informação sobre suas competências e potencialidades, não somente da área, mas também na área, e fortalecer as sociedades que estudam a disciplina. Resumidamente, infere-se que o auxílio ao desenvolvimento estaria fundado na maior criação científica e divulgação das pesquisas. Outro aspecto que pode ser inferido é a divulgação da área dentro das faculdades de psicologia, talvez com palestras, encontros, colóquios e congressos.

No artigo publicado por Rebustini e Machado (2012), são pesquisadas as dinâmicas sociais e as influências nos estados de humor. Os autores observaram como se daria a interferência dos familiares, de amigos e do ambiente escolar, os quais eles denominaram como "dinâmicas sociais", e discorreram como as manifestações das emoções se apresentavam nos indivíduos que praticavam atividades físicas. A pesquisa foi feita com atletas de vôlei com idades entre 14 e 15 anos. A conclusão encontrada foi que a preparação do atleta também necessita de interferências sociais, e que, como os psicólogos desportivos devem estar atentos a estes fatores. Percebeu-se que a utilização de instrumentos validados para verificar aspectos que interferem no contexto esportivo pode ser de grande utilidade. Finalizando, é também pontuado, porém não menos importante, a constatação de que existem interferências causadas pela mídia, dinheiro, cláusulas contratuais, empresários, agentes e patrocinadores.

Outro aspecto que é destacado nos estudos da psicologia do esporte e do exercício é a importância do espaço familiar, e isso além de ser um ponto com muitos estudos, devido a sua relevância, deve sempre estar ligado à necessidade de promover mais conhecimentos (Silami Garcia \& Lemos, 2002). Para Dobránszky (2005), o processo de humanização pode ser facilitado ou dificultado dependendo de como as relações familiares se desenvolvem. E estas, ainda são mais fortemente percebidas quando os atletas são jovens ou estão iniciando em determinada modalidade esportiva.

Esta dissertação, como forma de compreender o máximo a noção da psicologia do esporte e do exercício como um todo, mas também com consciência de suas limitações, tenta explorar as diversas facetas para que se tenha um panorama sobre a abrangência dos estudos iniciais e atuais da área. Além disso, essa área não se limita ao esporte de alto rendimento. Os psicólogos e outros profissionais que atuam no campo devem procurar identificar meios de favorecer pessoas de todas as idades, e compreender as diversas intenções e objetivos para os indivíduos realizarem atividade física, a fim de todos se beneficiarem.

No artigo "A produção de sentidos subjetivos e as configurações subjetivas na especialização esportiva", escrito por Dobránszky (2005) o objetivo foi analisar a produção de sentidos de um sujeito específico, de forma qualitativa, ao longo do processo de especialização esportiva com uma equipe de técnicos e atletas em um time de triatlo. 
Embora esse tema não seja inédito, existe a necessidade de se dar atenção por parte dos psicólogos esportivos, devido à supervalorização da vitória na nossa sociedade contemporânea. A ênfase dada aos resultados de competições esportivas em detrimento do bem estar pessoal do atleta, não deveria ser o que prevalece. Essa ideia da competição não se restringe apenas ao meio esportivo, mas é uma característica dos padrões sociais, e que aparece de diversas formas, se desprezando quando não se atinge o maior lugar do pódio.

A individualidade do praticante de atividade física se articula com a subjetividade social, e nesse estudo de Dobránszky (2005) é destacado o modo complementar e recursivo que ambos devem ser investigados, a fim de compreender como a especialização esportiva legitima o papel da vitória para os praticantes de atividades físicas em geral. A análise do artigo mencionado parte de uma abordagem histórica cultural, que considera o passado do sujeito, e todas as atividades que este participa, como uma produção subjetiva complexa, a qual se expressa de forma particular tanto na subjetividade social quanto na individual. Essas características são unificadas e transitam entrelaçadas quando compõem o ambiente esportivo. 


\section{Capítulo 2 - FORMAÇÃO DO PSICÓLOGO DO ESPORTE}

\section{A formação em Psicologia no Brasil}

Dois dos primeiros documentos que tratam da regulamentação da Psicologia como profissão no Brasil e do Currículo Mínimo dos cursos de Psicologia são de 1962. A profissão foi regulamentada prevendo-se três habilitações: a de bacharel, a de licenciatura e a de psicólogo, sendo que apenas na última era permitido o exercício pleno da profissão. A respeito das condições para funcionamento do curso, a Lei 4.119 preconizava que os cursos deveriam oferecer serviços supervisionados pelos professores nas três áreas de atuação do psicólogo, ou seja, clínica, educação e trabalho. Em seu preâmbulo, traz que a lei "dispõe sobre os cursos de formação em psicologia e regulamenta a profissão de psicólogo".

Após essa Lei, de 27/08/1962, vários documentos foram elaborados a fim de tratar e sistematizar questões práticas, sendo os mais importantes a resolução que cria o Currículo Mínimo (Brasil, 1962b) e o parecer que a ela se refere (Parecer n. 403/62 do CFE, 1962).

A partir da década de 1980, com a finalidade de discutir a formação e o exercício profissional em Psicologia, o Conselho Federal de Psicologia (CFP) promoveu uma série de atividades. Em 1983, iniciou amplo debate sobre problemas no exercício da profissão e necessidade de reformulação do currículo em Psicologia. Interessado em definir o perfil do psicólogo brasileiro e com o apoio de autores e pesquisadores, trabalhou-se a questão da formação do psicólogo no Brasil com estudos que geraram várias publicações (CFP, 1994).

O primeiro deles, intitulado Carta de Serra Negra (CFP, 1992), foi elaborado em um evento que envolveu a participação de 98 das 103 instituições de ensino superior do país que ofertavam cursos de Psicologia à época. Foi um marco divisor de águas, tanto em termos políticos, pela mobilização que provocou quanto em termos do conteúdo das propostas (Bernardes, 2004), o que realça a importância desse documento. A proposta colocada envolvia a elaboração de princípios que deveriam nortear a formação no currículo e nos estágios. Havia forte ênfase sobre compromisso ético da Psicologia com a realidade social. De acordo com Francisco e Bastos (1992), esse encontro contemplou a necessidade de mudanças profundas no processo de formação, as quais algumas deveriam envolver reformas curriculares.

O primeiro plano de Diretrizes Curriculares em Psicologia é de 2004. Gomes (1996, p.40) pontua sobre a tradição curricular inaugurada em 1962 na Psicologia: "[o] Currículo 
para os cursos de Psicologia proposto em 1962 refletia a lógica de uma formação que vai dos fundamentos e da experimentação para os estágios profissionais e para a aplicação".

Uma das notáveis diferenças que as DCN de 2004 apresentavam era em relação à forma que os estágios seriam estabelecidos. Esses, que deveriam estar presentes nos currículos de formação em Psicologia, foram considerados de extrema relevância para a capacitação e formação profissional.

Após amplas discussões, em 2011, foi instituído um novo Plano de Diretrizes Curriculares Nacional para o curso de Psicologia. Este foi idealizado a fim de estabelecer, também, normas que guiavam o projeto pedagógico complementar para a Formação de Professores de Psicologia (DCN, 2011). O início do processo de atualização desse novo plano surgiu, coletivamente, dos marcos políticos realizados anteriormente que debatiam o que deveria conter nas DCN. A complexidade dos diálogos buscou responder as demandas que surgiram na formação de professores de Psicologia, já anteriormente apresentadas no plano de DCN para cursos de Graduação em Psicologia de 2004 (DCN, 2004).

A partir da leitura das DCN de 2004 e o 2011, podemos nortear quais são os objetivos do Curso de Psicologia no Brasil:

-Proporcionar conhecimentos científicos para alicerçar a compreensão da natureza dos fenômenos psicológicos e dos comportamentos dos indivíduos em sua história pessoal, familiar e social.

-Proporcionar conhecimentos científicos e princípios éticos para a utilização de instrumentos e metodologias de análise e intervenção psicológicas.

-Formar psicólogos que atuem enquanto agente de transformação da realidade social, na direção da construção de uma sociedade mais justa e democrática.

-Ampliar o espaço de participação do aluno como sujeito de sua própria formação.

-Desenvolver no aluno a capacidade de debate e articulação com as diversas áreas do conhecimento, visando atuações interdisciplinares.

Esses objetivos foram construídos a partir das bases construídas pelas DCN, utilizando-se e relacionando-se com os Compromissos e Princípios definidos, que visam:

-Construção e desenvolvimento do conhecimento científico em Psicologia.

-Compreensão dos múltiplos referenciais que buscam apreender a amplitude do fenômeno psicológico em suas interfaces com os fenômenos biológicos e sociais.

-Reconhecimento da diversidade de perspectivas necessárias para compreensão do ser humano e incentivo à interlocução com campos de conhecimento que permitam a apreensão da complexidade e multideterminação do fenômeno psicológico;

-Compreensão crítica dos fenômenos sociais, econômicos, culturais e políticos do País, fundamentais ao exercício da cidadania e da profissão. 
-Atuação em diferentes contextos, considerando as necessidades sociais, os direitos humanos, tendo em vista a promoção da qualidade de vida dos indivíduos, grupos, organizações e comunidades.

-Respeito à ética nas relações com clientes e usuários, com colegas, com o público e na produção e divulgação de pesquisas.

-Aprimoramento e capacitação contínua.

O Código de Ética do Psicólogo relaciona-se diretamente com as DCN. Entre essas relações, verifica-se a prática para o exercício de legítimas Competências e Habilidades Gerais, estabelecidas desde o começo da regularização da área (Lei 5.766/1971). Estas são:

-Atenção à saúde: estar apto a desenvolver ações de prevenção, promoção, proteção e reabilitação da saúde psicológica e psicossocial, em nível individual e coletivo, no mais alto padrão de qualidade e princípios éticos.

-Tomada de decisões: fundamentar seu trabalho na capacidade de avaliar, sistematizar e decidir as condutas mais adequadas, baseadas em evidências científicas.

-Comunicação: ser acessível e manter os princípios éticos no uso das informações confidenciais, na interação com outros profissionais de saúde e com o público em geral.

-Liderança: estar apto a assumir posições de liderança, em equipes multiprofissionais, tendo em vista o bem estar da comunidade.

-Administração e gerenciamento: estar apto a tomar iniciativas, fazer 0 gerenciamento dos recursos humanos, físicos, materiais e de informação, bem como estar apto a ser empreendedor, gestor, empregador ou líder nas equipes de trabalho.

-Educação permanente: ser capaz de aprender continuamente, tanto na sua formação, quanto na sua prática e ter responsabilidade com sua educação e o treinamento das futuras gerações de profissionais, estimulando e desenvolvendo a mobilidade acadêmica e profissional, a formação e a cooperação através de redes nacionais e internacionais.

Recentemente, foi estabelecida a Portaria Inep oㅡ 243, de 10 de junho de 2015, e publicada no Diário Oficial de 12 de junho de 2015. Nesse documento, o Inep pretende avaliar diferentes pontos da formação dos estudantes, os quais destacamos os mais relevantes para o presente trabalho:

Art. 1ํ O Exame Nacional de Desempenho dos Estudantes (Enade), parte integrante do Sistema Nacional de Avaliação da Educação Superior (Sinaes), tem como objetivo geral avaliar o desempenho dos estudantes em relação aos conteúdos programáticos previstos nas diretrizes curriculares, às habilidades e competências para a atualização permanente e aos conhecimentos sobre a realidade brasileira e mundial, bem como sobre outras áreas do conhecimento. 
A partir da leitura do artigo 1ํㅡㄹ verifica-se a importância dada ao exame que visa verificar como os estudantes estão se capacitando, e se as metas e objetivos propostos nas DCN estão sendo atingidos.

Art. 5 A prova do Enade 2015, no componente específico da área de Psicologia, tomará como referência do perfil do egresso as seguintes características:

I - compromisso com a construção e o desenvolvimento do conhecimento científico em Psicologia;

II - compreensão da especificidade dos fenômenos e processos psicológicos e dos múltiplos referenciais teóricos e epistemológicos;

III - interlocução com campos de conhecimento para apreender a complexidade e a multideterminação do fenômeno psicológico, em suas interfaces com fenômenos sociais e biológicos;

IV - aptidão para atuar em diferentes contextos de inserção profissional, com postura crítica frente aos contextos macrossociais, tendo em vista a promoção dos direitos humanos e da qualidade de vida dos indivíduos, grupos, organizações e comunidades;

$V$ - compromisso com a ética no que diz respeito às relações com usuários, com colegas, com o público e na produção e divulgação de pesquisas, trabalhos e informações da área da Psicologia;

VI - atuação inter e multiprofissional, sempre que a compreensão dos processos e fenômenos envolvidos assim o recomendar, relacionando-se com o outro de modo a propiciar o desenvolvimento de vínculos interpessoais requeridos na sua atuação profissional;

VII - compromisso com o aprimoramento e a capacitação contínuos, atento ao desenvolvimento da Psicologia enquanto ciência e profissão.

A própria Portaria Inep №243 pontua que o Código de Ética da Psicologia, ao estabelecer padrões esperados quanto às práticas referendadas pela respectiva categoria profissional e pela sociedade, procura fomentar a autorreflexão exigida de cada indivíduo acerca da sua práxis, de modo a responsabilizá-lo, pessoal e coletivamente, por ações e suas consequências no exercício profissional.

A formação generalista encontrada nas $\mathrm{DCN}$, para os cursos de graduação em Psicologia assegura uma formação baseada na diversidade de perspectivas necessárias para compreensão crítica do ser humano, fundamental ao exercício da profissão e da cidadania, levando em consideração fenômenos sociais, econômicos e culturais. Porém, não deixa em nenhum momento o rigor científico e 0 aprofundamento desses conhecimentos.

Ressaltamos alguns pontos específicos das DCN de 2011 para facilitar a compreensão do que vem sendo apresentado e deixar claro o que foi estabelecido: 
Art. 1ํ A presente Resolução institui as Diretrizes Curriculares Nacionais para os cursos de graduação em Psicologia, a serem observadas pelas Instituições de Ensino Superior do País.

Art. $2^{\circ}$ As Diretrizes Curriculares para os cursos de graduação em Psicologia constituem as orientações sobre princípios, fundamentos, condições de oferecimento e procedimentos para o planejamento, a implementação e a avaliação deste curso.

Percebemos com a leitura do artigo $2^{\circ}$ que a fundamentação da construção do plano das DCN está sob a égide de uma base de princípios morais e sociais, a fim de promover ao estudante universitário um currículo diferenciado, bem estruturado, generalista e padronizado. Continuando:

Art. 3 O curso de graduação em Psicologia tem como meta central a formação do psicólogo voltado para a atuação profissional, para a pesquisa e para o ensino de Psicologia, e deve assegurar uma formação baseada nos seguintes princípios e compromissos:

I - construção e desenvolvimento do conhecimento científico em Psicologia;...

Art. 5o $A$ formação em Psicologia exige que a proposta do curso articule os conhecimentos, habilidades e competências em torno dos seguintes eixos estruturantes: I Fundamentos epistemológicos e históricos que permitam ao formando o conhecimento das bases epistemológicas presentes na construção do saber psicológico, desenvolvendo a capacidade para avaliar criticamente as linhas de pensamento em Psicologia; II Fundamentos teórico-metodológicos que garantam a apropriação crítica do conhecimento disponível, assegurando uma visão abrangente dos diferentes métodos e estratégias de produção do conhecimento científico em Psicologia; III - Procedimentos para a investigação científica e a prática profissional, de forma a garantir tanto o domínio de instrumentos e estratégias de avaliação e de intervenção quanto a competência para selecioná-los, avaliálos e adequá-los a problemas e contextos específicos de investigação e ação profissional; IV - Fenômenos e processos psicológicos que constituem classicamente objeto de investigação e atuação no domínio da Psicologia, de forma a propiciar amplo conhecimento de suas características, questões conceituais e modelos explicativos construídos no campo, assim como seu desenvolvimento recente; $V$ - Interfaces com campos afins do conhecimento para demarcar a natureza e a especificidade do fenômeno psicológico e percebê-lo em sua interação com fenômenos biológicos, humanos e sociais, assegurando uma compreensão integral e contextualizada dos fenômenos e processos psicológicos; VI Práticas profissionais voltadas para assegurar um núcleo básico de competências que permitam a atuação profissional e a inserção do graduado em diferentes contextos institucionais e sociais, de forma articulada com profissionais de áreas afins. 
Com a leitura desses artigos, verificamos que a elaboração das DCN visa além de pontuar a necessidade de se ter um curso com uma base metodológica e epistemológica forte, com preceitos científicos notáveis, também é bem exposta a importância e relevância de se ter uma prática profissional na graduação. Os amplos conhecimentos adquiridos devem ser interligados, entrelaçados e contextualizados com o contexto real e social.

Outro ponto interessante que deve ser mencionado a partir da leitura do artigo $5^{\circ}$ é a de promoção e incentivo à pesquisa acadêmica. As universidades devem tentar promover e criar estratégias que possam estimular a produção científica dos futuros psicólogos.

Art. $8^{\circ}$ As competências reportam-se a desempenhos e atuações requeridas do formado em Psicologia, e devem garantir ao profissional o domínio básico de conhecimentos psicológicos e a capacidade de utilizá-los em diferentes contextos que demandam a investigação, análise, avaliação, prevenção e atuação em processos psicológicos e psicossociais e na promoção da qualidade de vida.

Art. 10. Pela diversidade de orientações teórico-metodológicas, práticas e contextos de inserção profissional, a formação em Psicologia diferencia-se em ênfases curriculares, entendidas como um conjunto delimitado e articulado de competências e habilidades que configuram oportunidades de concentração de estudos e estágios em algum domínio da Psicologia.

A instituição de graduação deve tentar promover múltiplos caminhos aos estudantes, a fim de explorar e fomentar espaços de reflexões, e com isso, a escolha de quais oportunidades ou direção que vai ser tomada, a partir de iniciativa subjetiva e pessoal de cada graduando.

Art. 21. Os estágios supervisionados visam assegurar o contato do formando com situações, contextos e instituições, permitindo que conhecimentos, habilidades e atitudes se concretizem em ações profissionais, sendo recomendável que as atividades do estágio supervisionado se distribuam ao longo do curso.

Art. 22. Os estágios supervisionados devem se estruturar em dois níveis - básico e específico - cada um com sua carga horária própria. $\S 1$ ำ $\mathrm{O}$ estágio supervisionado básico incluirá o desenvolvimento de práticas integrativas das competências e habilidades previstas no núcleo comum. $\S 2^{\circ}$ Cada estágio supervisionado específico incluirá 0 desenvolvimento de práticas integrativas das competências, habilidades e conhecimentos que definem cada ênfase proposta pelo projeto de curso. $\S 3^{\circ}$ Os estágios básico e específico deverão perfazer, ao todo, pelo menos, 15\% (quinze por cento) da carga horária total do curso.

Mais uma vez, ressaltamos nas leituras acima que as práticas profissionais pelos estudantes de graduação, através de estágios supervisionados, são de grande importância para as DCN. O contato com a prática pode trazer grandes benefícios e esclarecimentos 
quanto às escolhas profissionais e áreas de aprimoramento do domínio científico psicológico.

De acordo com o Conselho Nacional de Educação (CNE), o conceito de estágio supervisionado consolidou-se, historicamente, no Brasil, ligado ao conjunto das Leis Orgânicas do Ensino Profissional, definidas no período de 1942-1946 (Brasil, 2003). Nessa época, os estágios supervisionados eram vistos como etapa preparatória para a ocupação de postos de trabalho. Representavam oportunidade aos alunos na formação. A ênfase estava colocada no estágio como campo de demonstração do ensino acadêmico.

Foi na década de 1970, com a implantação da Lei Federal № 5.692/71 (Lei n. 5.692, 1971), para o nível médio, que os estágios curriculares supervisionados ganharam força e cresceram em importância. A partir daí, passou-se a considerar o estágio supervisionado como obrigatório para as habilitações profissionais técnicas dos setores primário e secundário da economia, bem como para a área de saúde.

Uma década após, o artigo $2^{\circ}$ do Decreto n 87.497 - que regulamenta o estágio de estudante de estabelecimentos de ensino superior - definiu como estágio curricular: "as atividades de aprendizagem social, profissional e cultural, proporcionadas ao estudante pela participação em situações reais de vida e trabalho em seu meio, sendo realizadas na comunidade em geral ou junto a pessoas jurídicas de direito público ou privado." (Decreto $\mathrm{n}^{\circ}$ $87.497,1982)$.

Temos assim uma ampliação do entendimento da função dos estágios profissionais. Esses agora não são tomados apenas como campo de ilustração do que é aprendido no contexto da sala de aula, mas também como campo de aprendizagem que possui elementos próprios e autônomos em relação ao ensino formal.

\section{Projeto Pedagógico do Curso de Graduação em Psicologia do Instituto de Psicologia da Universidade de Brasília (PPC IP/UnB)}

O PPC IP/UnB segue os parâmetros construídos nas Diretrizes Curriculares Nacionais para os Cursos de Graduação em Psicologia, com o Plano de Desenvolvimento Institucional (PDI), com o Projeto Pedagógico Institucional (PPI/UnB) e com a estrutura acadêmica da Universidade de Brasília. O candidato ao Curso de Graduação em Psicologia da UnB ingressa na habilitação de Psicólogo e poderá optar pela segunda habilitação ao escolher uma entre as habilitações de Licenciatura em Psicologia e de Bacharel em Psicologia. 
O PPC IP/UnB busca pontuar competências e especialidades do corpo docente do Instituto de Psicologia (IP), o que possibilita ampla formação com visão crítica dos fundamentos epistemológicos, teórico-metodológicos, assim como dos procedimentos de pesquisa e da prática profissional.

O projeto prevê a integração dos estudantes do IP com as demais unidades da Universidade de Brasília e com outras instituições de ensino superior do país, por meio do Convênio de Mobilidade Estudantil da ANDIFES, e do exterior, por meio de Convênios Internacionais. As atividades realizadas pelo estudante nessas instituições, se compatíveis com o desenvolvimento de competências e habilidades do curso de Psicologia, podem ser reconhecidas para compor a integralização da carga horária do curso.

O Curso de Graduação em Psicologia da UnB está em consonância com o Estatuto da Universidade de Brasília (Resolução do Conselho Diretor n 13/03, de 19 de outubro de $2003^{1}$ ); com o Regimento Geral da Universidade de Brasília (Resolução do Conselho Diretor da FUB $n^{\circ}$ 015/2000²); com o Regimento Interno do Instituto de Psicologia ${ }^{3}$, com Resoluções do Conselho de Ensino, Pesquisa e Extensão (CEPE) e demais legislações de Colegiados Superiores do Instituto de Psicologia da Universidade de Brasília.

Em 2008, a Universidade de Brasília contava com cerca de 28.567 estudantes distribuídos entre 64 cursos de graduação, 62 programas de mestrado acadêmico, 49 programas de doutorado e vários cursos de especialização e mestrados profissionalizantes. Esses números estão em rápido crescimento com a gradual implantação, iniciada em 2009, do Programa de Reestruturação e Ampliação do Ensino de Graduação, do qual o Instituto de Psicologia faz parte. Em consonância com políticas de mobilidade entre instituições de ensino superior, de ação afirmativa e de inclusão social os cursos de graduação contam com estudantes estrangeiros, cotistas, indígenas, bem como pessoas com necessidades especiais. Em 2015, a Universidade de Brasília contava com cerca de 45 mil estudantes distribuídos entre 130 cursos de graduação, 127 programas de mestrado, 101 programas de doutorado, 29 programas de residência médica e vários cursos de especialização e mestrados profissionalizantes.

\footnotetext{
${ }^{1}$ Aprovado na $348^{\text {a }}$ Reunião Ordinária do Conselho Diretor da FUB, realizada em 15/10/2003, tendo em vista o disposto no Art. 11 da Lei n ${ }^{\circ} 3.398$, de 15/12/1961.

${ }^{2}$ Aprovado na $413^{\text {a }}$ Reunião Ordinária do Conselho Diretor da FUB, realizada em 07/09/2000, sob a minuta do Regimento Geral da UnB, aprovada no CONSUNI em sua $290^{\circ}$ Reunião Ordinária, realizada em 28/04/2000, cuja ata foi aprovada na $291^{\mathrm{a}}$ Reunião Ordinária de 26/05/2000).

${ }^{3}$ Aprovado pelo Conselho do Instituto de Psicologia em sua reunião de número 17/05, concluída em 10 de novembro de 2005.
} 


\section{O Instituto de Psicologia da Universidade de Brasília}

Em 1963 foi criado o então, Departamento de Psicologia como parte do Instituto Central de Ciências Humanas da UnB. Nesse mesmo ano, a professora Carolina Bori convidou o professor americano Fred Keller para colaborar na formação desse departamento. Em consequência do aceite de Keller, os professores Carolina Bori, Rodolfo Azzi e Gilmour Sherman (então da Universidade de São Paulo - USP) foram aos Estados Unidos com o objetivo de comprar equipamentos de laboratório e livros. Das discussões oriundas dessa viagem nasceu um método novo de ensinar, hoje conhecido em toda parte como instrução personalizada.

O Curso de Graduação em Psicologia teve início em 1ํ de agosto de 1963 com as habilitações Psicólogo, Licenciado em Psicologia e Bacharelado em Psicologia. O ato de reconhecimento do curso foi efetivado por meio do Decreto $N^{\circ} 74.194$, de 20/06/1974. Em 1964, foi iniciado o curso de pós-graduação - Curso de Mestrado em Psicologia - visando à preparação de pesquisadores e professores que posteriormente integrariam o corpo docente daquele departamento. Nesse mesmo ano, o Departamento de Psicologia foi transferido para o Instituto Central de Biologia.

Em 1966, o Departamento de Psicologia passou a ser denominado Instituto Central de Psicologia (ICP), sendo oficialmente incluído no Estatuto da UnB e aprovado pelo Conselho Federal de Educação em novembro de 1968 (Departamento de Psicologia, 1987). Também em 1966 foi criado o Centro de Pesquisas Psicológicas (CPP), que tinha como responsabilidade ministrar disciplinas de Psicologia para os discentes da UnB e formar graduados em Psicologia. Ao CPP também competia desenvolver e conduzir projetos de pesquisas. De 1964 a 1969, o Curso de Graduação e o curso de Mestrado funcionaram efetivamente. Entretanto, a crise política do país levou a uma grande perda do quadro docente da UnB, sendo o Curso de Mestrado desativado em 1969. Após esse ano, a Psicologia na UnB dedicou-se às atividades de ensino de graduação e à expansão da equipe de professores, considerando as várias orientações teórico-metodológicas da Psicologia.

Na reestruturação organizacional da UnB, em 1970, um conjunto de iniciativas de cunho político determinou que a Psicologia voltasse a ser Departamento, desta feita como parte do Instituto de Ciências Biológicas, mantendo as mesmas atividades e atribuições que desempenhava enquanto Instituto, no que diz respeito ao ensino, à pesquisa e à extensão. Esses empreendimentos, no conjunto, culminaram, em 1987 com a reorganização da unidade de Psicologia da UnB que retornou a Instituto com quatro departamentos: Departamento de Processos Psicológicos Básicos (PPB), Departamento de Psicologia 
Escolar e do Desenvolvimento (PED), Departamento de Psicologia Clínica (PCL) e Departamento de Psicologia Social e do Trabalho (PST).

Nesse contexto, o Instituto de Psicologia se desenvolveu e realizou suas funções, oferecendo, desde sua criação e com intensidade crescente a partir da década de 1970, cursos de pós-graduação stricto e lato sensu.

Atualmente, o Instituto de Psicologia oferece um curso de graduação continua com as habilitações de Psicólogo, Bacharel em Psicologia e de Licenciatura em Psicologia e oferece quatro Programas de Pós-graduação nos níveis de Mestrado e de Doutorado. Além disso, oferece cursos de Pós-graduação lato sensu.

Há, ainda, espaço para o desenvolvimento de outras atividades acadêmicas. A UnB, por meio do Centro de Desenvolvimento Tecnológico, fomenta a criação de empresas juniores que oferecem ao estudante oportunidades adicionais de treinamento para 0 trabalho. No caso do IP, a Empresa de consultoria Júnior existente denomina-se PRAXIS Consultoria Jr., e seus trabalhos são desenvolvidos sob supervisão de professores do IP, envolvendo estudantes de graduação.

Outros programas em nível de graduação estimulam a participação do discente no âmbito da pesquisa e da extensão. Nesse sentido, o Programa Institucional de Bolsas de Iniciação Científica (ProlC) visa inserir o estudante em projetos de pesquisa desenvolvidos por professores/pesquisadores da instituição. Por sua vez, o Programa Institucional de Bolsas de Extensão (PIBEX) visa inserir o estudante em atividades de extensão por meio de projetos de ação contínua desenvolvidos por professores e extensionistas da instituição.

O Programa de Educação Tutorial (PET/SESu/MEC) é também desenvolvido no IP. O objetivo é propiciar aos estudantes de graduação (via processo seletivo), condições para a realização de atividades extracurriculares (e.g., palestras, seminários, visitas a instituições, participação em congressos, atividades de extensão e de pesquisa). Essas atividades contribuem para a formação acadêmica, visando à integração no mercado de trabalho e em programas de pós-graduação. O PET-PSI/UnB também promove diversos eventos abertos à comunidade acadêmica (e.g., palestras e seminários), além de publicar o jornal PETrechos com artigos de estudantes e professores do IP, de outras unidades ou centros da UnB e de outras instituições.

Outras oportunidades de aprimoramento da formação universitária ocorrem com a contribuição de unidades acadêmicas da UnB, por meio de eventos, programas de extensão de ação contínua e programas especiais dos Decanatos de Graduação (DEG), Extensão (DEX), Pós-Graduação (DPP) e Assuntos Comunitários (DAC).

A concepção curricular flexível, associada a uma ampla oportunidade de envolvimento de estudantes de graduação em projetos de pesquisa, de extensão e uma política objetiva de integração das atividades, tem conferido ao curso de graduação do IP as 
condições essenciais para a realização dos objetivos de uma formação profissional diferenciada.

\section{O Curso de Graduação em Psicologia Reestruturação Curricular}

O currículo da formação das três habilitações é constituído a partir de várias competências e habilidades em comum, o que resulta em várias disciplinas e atividades em comum. O estudante ingressará no curso na habilitação Psicólogo e poderá solicitar, a partir do $7^{0}$ período, a dupla formação ao escolher uma entre as habilitações de Bacharel e Licenciatura em Psicologia, e podendo assim, cursar simultaneamente duas habilitações.

\section{Ênfases Curriculares}

O curso de Psicologia possui uma oferta ampla de disciplinas optativas, dando mais abertura ao aluno para escolher seus estudos de maior interesse. Além disso, apresenta uma diversidade de temas, objetos de investigação em diferentes laboratórios do IP, envolvendo trabalhos empíricos e teóricos. A integração entre a graduação e os programas de pós-graduação do IP favorece a formação do profissional pesquisador em Psicologia, desde os primeiros períodos do estudante na graduação.

O IP, ao longo de sua existência, desenvolveu um marcante compromisso com a formação generalista e com a pesquisa, integrando amplamente a graduação e a pósgraduação, de forma a representar todo o escopo de atuação da Psicologia. Um exame dos temas e problemas da Psicologia abordados pelos diversos laboratórios com suas linhas de pesquisa, disciplinas oferecidas na graduação e atividades desenvolvidas em pesquisa e extensão mostram a abrangência e a diversidade dessa formação. O curso também oferece oportunidades para o aprofundamento nas áreas de interesse dos estudantes, propiciando escolhas significativas para além do Núcleo Comum.

\section{Competências da Formação do Psicólogo}

São Competências do Psicólogo: (1) Fundamentar a atuação do psicólogo conforme os preceitos da ética profissional; (2) Compreender a inter-relação entre abordagens teóricas e diversidades metodológicas; (3) Desenvolver e utilizar procedimentos metodológicos, técnicas e instrumentos de pesquisa científica em Psicologia, compatíveis com as especificidades do objeto de estudo e da prática profissional; (4) Realizar intervenções psicológicas de acordo com as características do contexto e do problema; (5) Realizar orientação, aconselhamento psicológico e psicoterapia; (6) Atuar em diferentes contextos promovendo a saúde e a qualidade de vida de pessoas; (7) Atuar em diferentes contextos promovendo o desenvolvimento e a inserção no mundo do trabalho de pessoas, 
grupos, organizações e comunidades; (8) Conhecer e utilizar instrumentos e metodologias de avaliação psicológica; (9) Analisar resultados do uso de instrumentos e metodologias de avaliação e de intervenção psicológica, a partir do referencial teórico-metodológico adotado; (10) Planejar e coordenar projetos de atuação profissional para diversos contextos.

\section{Estrutura Curricular}

A Estrutura Curricular da UnB, para todos os cursos, é organizada em módulo integrante e módulo livre. O primeiro é constituído pela Área de Concentração e pela Área Conexa do curso; e o segundo, pelos conteúdos de áreas de conhecimento e campos de atuação que despertem o interesse do estudante. Para assegurar a flexibilidade planejada no currículo, a organização da estrutura curricular faz uso de disciplinas obrigatórias, optativas e obrigatórias seletivas, estas últimas formando um conjunto de disciplinas dentre as quais o estudante deverá fazer uma seleção.

\section{Pesquisa}

O Artigo 19 (DCN, 2004) indica que o planejamento acadêmico deve assegurar ao egresso, em termos de carga horária e de planos de estudos, o envolvimento em projetos de pesquisa desenvolvidos por docentes do curso. Além da disponibilidade institucional do Programa de Iniciação Científica, o Projeto Pedagógico do Curso de Psicologia IP/UnB dispõe de mecanismos internos para o envolvimento do aluno com a atividade científica, por meio de disciplinas de Pesquisa. Elas contemplam diferentes áreas de estudo e geram um registro acadêmico correspondente às atividades de pesquisa nas quais os estudantes estão matriculados.

\section{Extensão}

A interação entre a Universidade de Brasília e a sociedade é estimulada via ações extensionistas, as quais integram as artes e a ciência ao ensino, pesquisa e desenvolvimento social. Projetos interdisciplinares envolvendo comunidades dão prosseguimento ao desenvolvimento científico, visando temas transversais que contribuem para práticas sociais e integração de políticas.

A Extensão universitária está prevista na Lei N 10.172/2001 (Plano Nacional de Educação, janeiro de 2001) a qual assegura que no mínimo $10 \%$ do total de créditos exigidos no Curso de Graduação sejam reservados para o registro acadêmico das atividades de Extensão realizadas pelos estudantes. 
Os objetivos do fortalecimento da Extensão nas universidades públicas são: (1) viabilizar a função social da universidade; (2) favorecer a concretização da prática universitária; (3) garantir a articulação entre Ensino, Pesquisa e Extensão e (4) estabelecer compromisso com o desenvolvimento do país e com a busca de soluções democráticas para os problemas nacionais.

O Colegiado de Graduação e Extensão do Instituto de Psicologia estabeleceu 8\% do total de créditos do curso para as atividades de Extensão na integralização dos créditos exigidos para a formação profissional em Psicologia. Algumas modificações são necessárias a partir da compatibilização dos itens anteriormente apresentados.

Em cumprimento à Resolução 2/2007 do Conselho Nacional de Educação, a qual estabelece no máximo $20 \%$ de estágio e atividades complementares, será estabelecido um total de $5 \%$ da carga total do curso (em cada habilitação do curso) destinado às Atividades Complementares.

\section{Estágios}

As Diretrizes Curriculares Nacionais (DCN, 2004) apresentam os estágios supervisionados curriculares como:

Conjuntos de atividades de formação, programados e diretamente supervisionados por membros do corpo docente da instituição formadora e procuram assegurar a consolidação e articulação das competências estabelecidas (Artigo 20, DCN, 2004).

Os estágios supervisionados visam assegurar o contato do formando com situações, contextos e instituições permitindo que conhecimentos, habilidades e atitudes se concretizem em ações profissionais, sendo recomendável que as atividades do estágio supervisionado se distribuam ao longo do curso (Artigo 21, DCN, 2004).

As Diretrizes Curriculares Nacionais (DCN, 2004) especificam ainda no Artigo 22 diferentes níveis para os estágios supervisionados:

Os estágios supervisionados devem se estruturar em dois níveis - básico e específico - cada um com sua carga horária própria.

§ $1^{\circ} \mathrm{O}$ estágio supervisionado básico incluirá o desenvolvimento de práticas integrativas das competências e habilidades previstas no Núcleo Comum.

$\S 2^{\circ}$ Cada estágio supervisionado específico incluirá o desenvolvimento de práticas integrativa das competências, habilidades e conhecimentos que definem cada ênfase proposta pelo projeto do curso.

§ 3ํㅡㄴ estágios básico e específico deverão perfazer, ao todo, pelo menos 15\% da carga horária total do curso. 
As disciplinas de Estágio Supervisionado (Básico e Específico) devem ser estruturadas em torno de situações-problema ou atividades práticas. De forma específica o Estágio deve oferecer ao aluno a oportunidade de consolidar e integrar competências próprias do Núcleo Comum, como a identificação e a descrição de necessidades, e o planejamento de atuação em situações que caracterizam o espectro de atuação do graduado em psicologia, as quais podem ser desenvolvidas nos grandes campos de atuação em saúde, educação e trabalho, quer através da pesquisa, ou do ensino ou da atuação profissional.

O Estágio Básico deverá envolver supervisão compartilhada envolvendo professores de diferentes departamentos, o que favorece a interação entre abordagens psicológicas. O Estágio Supervisionado Básico deve anteceder necessariamente, na grade curricular, os Estágios Supervisionados Específicos.

O Estágio Específico deve assegurar ao aluno o desenvolvimento de competências diferenciadas, vinculadas à identidade do perfil de escolha, em diferentes contextos tais como hospital, tribunal, escola, comunidades específicas e outras organizações públicas e privadas. Estas disciplinas devem ser planejadas com um número máximo de alunos por professor para garantir o trabalho de supervisão tutorial eficiente.

Assim, o Estágio Básico e os Estágios Específicos proporcionarão ao estudante: (1) maior articulação entre as dimensões teórica e prática a partir do quarto período do curso; (2) interlocução entre as diferentes abordagens da Psicologia e entre outras áreas afins do conhecimento; e (3) formulação de perguntas a partir de um referencial teórico, o qual apresentará alternativas metodológicas de coleta e análise de dados, assim como de intervenção. Portanto, trata-se de uma oportunidade de aprendizagem focada em situaçõesproblema ou no desenvolvimento de projetos que possibilitem a interação de diferentes referenciais teóricos da Psicologia, apresentados nas diversas áreas de atuação do profissional pesquisador e representadas nas disciplinas, conforme o desenho curricular.

Além dos Estágios Supervisionados Obrigatórios (Estágio Básico e Estágios Específicos), a partir da Lei $\mathrm{N}^{\circ} 11.788$, de 25 de setembro de 2008, define-se o Estágio Não-Obrigatório:

Art. 2ำ Estágio poderá ser obrigatório ou não-obrigatório, conforme determinação das diretrizes curriculares da etapa, modalidade e área de ensino e do projeto pedagógico do curso

Parágrafo $1^{\circ}$ Estágio obrigatório é aquele definido como tal no projeto do curso, cuja carga horária é requisito para aprovação e obtenção de diploma.

Parágrafo $2^{\circ}$ Estágio não-obrigatório é aquele desenvolvido como atividade opcional, acrescida à carga horária regular e obrigatória. 
As propostas fornecidas pelas DCN de 2011 foram amplamente estudadas e utilizadas pelos novos currículos apresentados pelo Instituto de Psicologia da UnB. Tanto na idealização da formação do aluno em Psicologia como a promoção de uma abertura e o incentivo nas ênfases dos estudos no processe de formação do psicólogo.

\section{O especialista em psicologia no Brasil}

A Resolução CFP 13/07 institui a Consolidação das Resoluções relativas ao Título Profissional de Especialista em Psicologia e dispõe sobre normas e procedimentos para seu registro.

Conforme é estipulado no artigo 8ํำ da Resolução:

Para habilitar-se ao Título de Especialista e obter o registro, o psicólogo deverá estar inscrito no Conselho Regional de Psicologia há pelo menos dois anos e atender a um dos requisitos que se seguem:

I - ter certificado ou diploma de conclusão de curso de especialização conferido por instituição de ensino superior legalmente reconhecida pelo Ministério da Educação e que esteja credenciada ao CFP;

II - ter certificado ou diploma de conclusão de curso de especialização, conferido por pessoa jurídica habilitada para esta finalidade, cujo núcleo formador esteja credenciado ao CFP e atenda aos seguintes requisitos: a) tenha pelo menos uma turma com curso já concluído; b) seja registrado no CRP da sua área de atuação, quando for o caso.

III - ter sido aprovado no exame teórico e prático, promovido pelo CFP, e comprovar prática profissional na área por mais de dois anos.

$\S 10$ - O CFP poderá delegar poderes a outras entidades para a realização do exame teórico e prático de que trata o inciso III.

Seguem as especialidades reconhecidas pelo CFP (CFP, 13/2007):

I. Psicólogo especialista em Psicologia Escolar/Educacional

II. Psicólogo especialista em Psicologia Organizacional e do Trabalho

III. Psicólogo especialista em Psicologia de Trânsito

IV. Psicólogo especialista em Psicologia Jurídica

V. Psicólogo especialista em Psicologia do Esporte

VI. Psicólogo especialista em Psicologia Clínica

VII. Psicólogo especialista em Psicologia Hospitalar

VIII. Psicólogo especialista em Psicopedagogia

IX. Psicólogo especialista em Psicomotricidade

X. Psicólogo especialista em Psicologia Social 


\section{Psicólogo especialista em Neuropsicologia}

\section{A Concessão}

O registro profissional de especialista deve ser solicitado ao Conselho Regional de Psicologia no qual o psicólogo tem sua inscrição principal. Cabe à plenária do CRP a aprovação da concessão do título profissional de especialista.

\section{Psicólogo especialista em Psicologia do Esporte}

Segundo a própria definição encontrada na resolução CFP 13/07: A atuação do psicólogo do esporte está voltada tanto para o esporte de alto rendimento, ajudando atletas, técnicos e comissões técnicas a fazerem uso de princípios psicológicos para alcançar um nível ótimo de saúde mental, maximizar rendimento e otimizar a performance, quanto para a identificação de princípios e padrões de comportamentos de adultos e crianças participantes de atividades físicas.

O psicólogo do esporte estuda, identifica e compreende teorias e técnicas psicológicas que podem ser aplicadas ao contexto do esporte e do exercício físico, tanto em nível individual - o atleta ou indivíduo praticante - como grupal - equipes esportivas ou de praticantes de atividade física. Sua atuação é tanto diagnóstica, desenvolvendo e aplicando instrumentos para determinação de perfil individual e coletivo, capacidade motora e cognitiva voltada para a prática esportiva, quanto interventiva atuando diretamente na transformação de padrões de comportamento que interferem na prática da atividade física regular e/ou competitiva.

São realizados estudos e pesquisas individualmente ou em equipe multidisciplinar, observando o contexto da atividade esportiva competitiva e não competitiva, a fim de conhecer elementos do comportamento do atleta, comissão técnica, dirigentes e torcidas; realiza atendimentos individuais ou em grupo, empregando técnicas psicoterápicas adequadas à situação, com o intuito de preparar o desempenho da atividade do ponto de vista psicológico; elabora e participa de programas e estudos de atividades esportivas educacionais, de lazer e de reabilitação, orientando a efetivação do esporte não competitivo de caráter profilático e recreacional, para conseguir o bem-estar e qualidade de vida dos indivíduos; desenvolve ações para a melhoria planejada e sistemática das capacidades psíquicas individuais voltadas para otimizar o rendimento de atletas de alto rendimento bem como de comissões técnicas e dirigentes; participa, em equipe multidisciplinar, da preparação de estratégias de trabalho objetivando o aperfeiçoamento e ajustamento do praticante aos objetivos propostos, procedendo ao exame de suas 
características psicológicas; participa, juntamente com a equipe multidisciplinar, da observação e acompanhamento de atletas e equipes esportivas, visando o estudo das variáveis psicológicas que interferem no desempenho de suas atividades específicas como treinos e competições. Orienta pais ou responsáveis nas questões que se referem a escolha da modalidade esportiva e a consequente participação em treinos e competições, bem como o desenvolvimento de uma carreira profissional, e as implicações dessa escolha no ciclo de desenvolvimento da criança.

E por fim, colabora para a compreensão e transformação das relações de educadores e técnicos com os alunos e atletas no processo de ensino e aprendizagem, e nas relações inter e intrapessoais que ocorrem nos ambientes esportivos. Colabora para a adesão e participação aos programas de atividades físicas da população em geral ou portadora de necessidades especiais.

O Título Profissional de Especialista em Psicologia, embora não constitua condição obrigatória para o exercício profissional, atesta o reconhecimento da atuação do psicólogo à determinada área, qualificando a formação do profissional.

\section{A Expansão da Psicologia do Esporte e do Exercício no Brasil}

Ao longo da década de 90 houve uma grande expansão de profissionais atuantes na área da Psicologia do Esporte e do Exercício, e isso repercutiu em conquistas de territórios que pudessem servir para atuar, em um número maior de publicações nacionais e uma busca mais intensiva de uma formação específica. Nesse crescimento do campo, e nessa década, se tem pela primeira vez nas universidades brasileiras o oferecimento da disciplina Psicologia do Esporte, além de algumas especializações latu sensu (Rubio, 2000).

Para Eliane Abdo (Abdo apud Rubio, 2000), a inclusão da disciplina Psicologia do Esporte nos currículos de psicologia proporcionaria maior visibilidade a esse campo de atuação. Alunos de graduação ao ter um contato com a área poderiam ser estimulados a fazer buscas a fim de se aprofundar, caso fosse de seu interesse. É relevante para a formação e educação dos alunos, o incentivo dos professores, que acima de tudo são educadores, para que sejam contempladas críticas e reflexões com o intuito de aprimoramento científico na Psicologia e da ciência como um todo.

A formação dos psicólogos do esporte e do exercício nas faculdades de Psicologia brasileiras é de certa forma recente. Até 1995 não existia, dentro das normas vigentes dos ministérios de educação dos países sul americanos. O primeiro curso de pós graduação (especialização) da América do Sul foi oferecido pela PUC/RS em Porto Alegre. Foram ofertadas quarenta vagas, todas foram prontamente preenchidas. Porém, com um detalhe 
interessante, 35 das vagas foram preenchidas por Educadores Físicos e apenas cinco por psicólogos. A princípio, estavam sendo oferecidas 20 vagas para cada área, mas a demanda foi consideravelmente desproporcional, então a surpresa foi grande (Becker, 2000).

A partir desse exemplo exposto, algumas hipóteses podem ser levantadas. Será que não havia interesse entre os psicólogos em atuar no campo esportivo? Será que os Educadores Físicos eram mais incentivados a trabalhar com a psicologia no final do século $X X$ ? Seria possível que o caráter de incentivo ao esporte dentro do curso de Educação Física fazia com que os graduados se sentissem mais confortáveis em atuar com a Psicologia do Esporte do que os psicólogos? Como estava se dando a formação em psicologia e se os graduados em psicologia estavam informados sobre a possibilidade de trabalhar no campo esportivo e do exercício?

Não respondendo a esses questionamentos, mas auxiliando para se usar como reflexão, outro dado é relevante: até a data em questão não existia nenhuma faculdade brasileira de Psicologia que oferecesse a disciplina Psicologia do Exercício ou do Esporte, enquanto nos 160 cursos de Educação Física existia alguma disciplina oferecida que aplicava a Psicologia à Educação Física (Becker Jr, 2000). Há ainda pouca conscientização quanto às possibilidades de se debruçar sobre o que a ciência dos esportes proporciona no âmbito da psicologia é vista como a explicação mais plausível para justificar esses dados

De acordo com Valdés (2000), diferentes são as maneiras que os psicólogos do esporte vêm se formando, sobretudo informais, e principalmente em países da América do Sul e da América Central. Desde palestras, conferências, congressos, seminários, e até com trabalhos práticos e conhecimentos empíricos. O que de certa forma é interessante para ressaltar a importância dada à construção de conhecimento, mas ao mesmo tempo, devemos sempre caminhar com passos embasados cientificamente, como a área exige.

\section{A Psicologia do Esporte na Universidade de Brasília}

Fundamentada no caráter generalista da formação em Psicologia, em conformidade com o Plano de Diretrizes curriculares, a primeira vez que a disciplina Psicologia do Esporte foi oferecida data do ano de 2008. A segunda vez foi em 2010, depois em 2013 e a última no primeiro semestre de 2015. Nesse último momento, o nome da disciplina foi alterado para Psicologia do Esporte e do Exercício, seguindo o entendimento epistemológico da área. A disciplina consiste em uma matéria de 4 créditos, 60 horas aula. Deve ter o aluno cursado, como pré requisito a disciplina de Introdução à Psicologia, Psicologia: curso e profissão ou Fundamentos do Desenvolvimento e Aprendizagem. 
A nova grade curricular tratou de incluir a Psicologia do Esporte e do Exercício como disciplina optativa do fluxo regular aos estudantes de graduação em 2013. Ela faz parte do quadro de disciplinas lotadas no departamento de Psicologia Escolar e do Desenvolvimento.

A ementa da disciplina traz os seguintes pontos: Objeto e campo da Psicologia do Esporte. Relação Psicologia e Esporte. Aspectos do desenvolvimento psicológico e atividade física. Formação e atuação do Psicólogo do Esporte. Práticas esportivas e recreação em grupo ou individualmente. Atividade física, sociedade, escola e Psicologia.

\section{O processo de tornar-se}

Dediquei-me a observar o processo pelo qual um indivíduo cresce e se modifica numa relação Terapêutica (Rogers, 2001).

Nessa sessão, adotaremos a perspectiva de Rogers sobre o processo de tornar-se pessoa, para compreendermos o processo de tornar-se psicólogo do esporte.

Rogers (2001) especifica seu ponto de vista diante do desenvolvimento da pessoa por meio de um prisma humanista da psicologia. $O$ autor fornece muitos exemplos, diálogos, reflexões, em uma conversa tanto científica quanto impessoal com muitas falas que dialogam diretamente com o leitor.

O livro "Tornar-se Pessoa", entre as obras de Rogers, destaca-se como eixo fundamental para a disseminação da Abordagem Centrada na Pessoa. Os escritos do autor possuem capacidade teórica e pragmática de utilizar sua experiência, e sua reflexão a posteriori sobre essa experiência, como alimentos para acessar verdadeiramente as pessoas. Além disso, ressalta esses alimentos como motivadores de sua compreensão do processo de tornar-se humano, e do ser e do estar no mundo tão singular e potencialmente mutável de cada ser humano.

O autoquestionamento rogeriano sobre a teoria e a prática sustenta as intervenções dentro das interações e a confiança genuína na força motriz anima o ser humano a crescer e a se superar. E por fim, a compreensão de que, em última instância, são as próprias pessoas que transformam as demais com as quais se relacionam. Dessa maneira, percebemos em Rogers que a pessoa não pode ser compreendida a não ser que seja verificada na experiência de alguma forma.

É sob essa perspectiva que "Tornar-se Pessoa" detém um caráter existencial. O autor propõe a revisão da existência da pessoa, dos seus padrões, posicionamentos, desejos, projetos, com a intenção de expandir a consciência do ser. São propostos espaços mais livres para a expressão, onde as pessoas possam ser compreendidas a partir de suas 
próprias vivências; onde possam compreender que a desconstrução e a reconstrução de valores, de políticas e de dinâmicas socioeconômicas podem, sim, ser marcadas pelo acolhimento de tudo que vem à tona.

Em relação à sombra da natureza humana, Rogers (2001) acredita que todos os problemas existenciais podem ser resolvidos se pudermos nos aceitar, nos compreender e nos tornamos coerentes em nossos afetos, pensamentos e comportamentos. $O$ autor constrói uma ênfase nesse processo de mudança ao longo de todos os seus escritos. Rogers ao verificar a possibilidade de descrever certas fases e suas ordens entre seus clientes coloca que diversas são as maneiras de se compreender, aprender, formar, criar ou se desenvolver como psicólogo.

O processo de tornar-se pessoa para Rogers, por meio das experiências do indivíduo no seu dia a dia, ou durante a terapia, explora as tomadas de consciência, sejam elas menos distorcidas da realidade, e onde essa pessoa se compreenda de maneira mais clara, honesta e livre. A partir desse momento de "auto honestidade" é que poderá realmente experimentar as sensações que está vivenciando. É colocada pelo autor a ideia de um filtro conceitual, este que deve ir deixando transpassar cada vez mais à medida que a tomada de consciência ocorre, ou seja, um filtro que existe a partir da desconfiança e inexperiência.

No desenvolvimento do indivíduo, quando este vai se enriquecendo livremente a partir das suas livres tomadas de consciência, a pessoa pode ir compadecendo de seus momentos iniciais de verdadeiro potencial do organismo humano. As reações sensoriais e viscerais mencionadas por Rogers tornam a pessoa o que ela é, de maneira real, pura, simples, mas também complexa. Resumidamente, pode-se dizer que a pessoa se torna na sua consciência aquilo que é na experiência. Portanto, percebemos que a realização contínua e constante de momentos vividos pelo indivíduo traz uma percepção que faz sentido no desenvolvimento da consciência do que é capaz e se acha capaz ou sobre quem realmente é. Sendo assim, os objetivos que o indivíduo busca por fim são de que ele possa se tornar ele mesmo.

A experiência fez com que a pessoa descobrisse quem ela é, na medida em que está aberta. A transparência e a aceitação dos momentos vivenciados vão nortear seus comportamentos, podendo perceber seus sentimentos e as exigências sociais que os outros adotam como verdades. Esses processos fornecem uma visão mais acurada das complexidades externas, alcançando equilíbrio e satisfações mais ponderadas de suas atividades.

Para Rogers, quando a pessoa se vê responsável por si, existem momentos de força demonstrados pela superação de obstáculos, mas também existem os desconfortos vividos nas sensações de responsabilidade sobre os seus atos. Nos momentos que essa 
pessoa se vê como resultados de seus atos, de suas escolhas, os valores assimilados pela realização de determinada experiência são pessoais. Ao atingir as finalidades esperadas, o indivíduo vai se percebendo em um processo que o torna alguém capaz de ser algo que ele espera ser.

Finalizando, segundo Rogers, ser apenas um produto dos seus atos não é o mais desejado pelo indivíduo, mas esse dá mais importância ao processo de se tornar esse produto. Ao se tornar, mesmo com as tarefas realizadas ou não, a pessoa sabendo quem é ou aonde vai, representa uma confiança no que é, e no que é capaz. Não existe um produto acabado, ou pessoa que chegou à estagnação, mas sempre em um processo, um curso contínuo. Esse é o processo de tornar-se pessoa para Rogers, a pessoa que está sempre disposta a enfrentar novas situações, desafios, mudanças, que está aprendendo, ganhando confiança, e descobrindo novos aspectos sobre si mesmo. 


\section{III- OBJETIVOS DA PESQUISA}

\section{Objetivo geral}

Compreender o processo de tornar-se psicólogo do esporte.

\section{Objetivos específicos:}

- Compreender a trajetória curricular de psicólogos do esporte.

- Analisar como o psicólogo passa a se reconhecer como psicólogo do esporte.

\section{IV- METODOLOGIA}

\section{Pressupostos Metodológicos}

De acordo com os objetivos, a pesquisa foi feita a partir dos pressupostos da pesquisa qualitativa em psicologia. Esse pressuposto compreende que o contato direto e prolongado do pesquisador com o ambiente e a situação que está sendo investigada possibilita o entendimento dos fenômenos influenciados pelas circunstâncias particulares da situação estudada, o que foi essencial para atender aos objetivos do nosso estudo. A abordagem qualitativa refere-se à investigação que produz informações descritivas e interpretadas a partir das próprias palavras dos sujeitos participantes da pesquisa, orais ou escritas, e a conduta observável. Por apresentar diversidade e flexibilidade, as investigações não admitem regras precisas (Trivinos, 1987).

Neste estudo, o interesse foi compreender o desenvolvimento do tornar-se psicólogo do esporte a partir dessa metodologia que prioriza o processo de formação do devir e não apenas o resultado final de uma formação. Sendo assim, a percepção que o pesquisador constrói ao longo da pesquisa sobre esse processo passa a ser criada em um diálogo na relação pesquisador/pesquisado.

Mantivemos as características de uma pesquisa qualitativa e embasando-nos no referencial teórico histórico e cultural do desenvolvimento humano, pudemos construir um conteúdo científico significativo e rico ao estabelecer a relação de entrevistador e entrevistado. González Rey (2002) esclarece que a pesquisa qualitativa é uma forma de produção de conhecimento, e não uma coleta de dados, visando apenas o número de sujeitos ou instrumento de pesquisa utilizados. Ao desenvolver qualitativamente a pesquisa, o sujeito pesquisador está comprometido de maneira ativa, constante e contínua nas suas interações com os sujeitos do estudo. Esse tipo de pesquisa proporciona diálogos regularmente, não unidirecionais e assume formas diversas e questionamentos novos a cada momento da pesquisa. 
Vigotski (1931/2000) pontua a necessidade de escolher e delimitar o seu objeto de estudo como sendo fundamental na definição metodológica da pesquisa. Dessa forma, para cada problema a ser investigado há um tipo de método que deve ser construído.

A partir dos ensinamentos de González-Rey (2002) sobre a pesquisa qualitativa, é destacada a ausência de uma separação entre os diversos momentos da construção do conhecimento. Isso se dá porque a todo tempo novos alicerces, ganchos e etapas encadeadas engajam-se de forma única e contínua. Dessa maneira, a pesquisa não seria compreendida como etapas ou barreiras a serem ultrapassadas, mas como um processo que se reorganiza com novas partes durante a investigação.

Dessa forma, a partir desses pressupostos, o presente trabalho utilizou-se da interação entre o pesquisador e os sujeitos pesquisados na construção e nas análises de informações do momento empírico. Sendo assim, utilizamos da flexibilidade e oportunidade de se desenvolver conteúdos sobre o fenômeno estudado juntamente com os entrevistados. Rompemos, dessa maneira, com o caráter positivista, puramente objetivo, e que acaba por neutralizar informações que considera a subjetividade como possibilidade de elaboração científica.

Entendemos que ao longo do processo de fazer ciência devemos levar em consideração certos pontos como fatos históricos e sociais, a subjetividade dos sujeitos e a construção das informações obtidas de forma coerente e dentro da lógica científica (Haaken, 1998). Para compreender a realidade é interessante que esta seja vista como uma rede de fenômenos não só baseada em fatos, mas ideias, ações, fatos e determinações pessoais e suas relações no tempo. As mudanças no mundo que são causadas pelo homem não são ocasionadas por suas ideias, mas são reflexos de suas ações práticas (Kopnin, 1978).

No pensamento de Duarte (2004), o ser humano forma-se e está sempre em transformação, se apropriando da cultura, a qual está inserida nas atividades sociais e históricas. Portanto, realiza novas formulações na medida em que busca uma adaptação no mundo ao seu redor.

Levamos em consideração essas idéias para compreendermos nossos objetivos entendendo que a formação do psicólogo do esporte envolve as experiências acumuladas nas interações sociais e históricas, possibilitando transformações ao longo do processo de formação profissional e pessoal. Essas práticas profissionais, no trabalho dos psicólogos que atuam com a psicologia do esporte e do exercício vão permitir a aquisição de novas capacidades e formulação contínua de novos conhecimentos.

A experiência pessoal pode proporcionar questionamentos e novas reflexões que possibilita aos psicólogos inseridos no meio do esporte e do exercício buscar maneiras de realizar um trabalho ético e científico. Os relatos obtidos na interação com os sujeitos 
entrevistados podem favorecer no entendimento das mudanças constantes que o campo do esporte e a ciência possuem.

Nesse sentido, utilizamos a entrevista semiestruturada em um processo de construção das informações, levando em consideração as peculiaridades e singularidades dos participantes.

\section{Contexto da pesquisa e participantes}

Os sujeitos desta pesquisa foram três psicólogos, duas mulheres e um homem, que atuam com a psicologia do esporte e do exercício no Distrito Federal. Todos eles são moradores de Brasília/DF, e formados na Universidade de Brasília, nos anos de 2004, 2008 e 2009. Entre os sujeitos, um é mestre em psicologia do desenvolvimento e outro mestre em educação física e doutor em educação. Estes dois também têm cursos de especialização em psicologia do esporte.

\section{Materiais e Instrumentos}

Para obter as informações no momento empírico foram utilizados os seguintes recursos materiais: roteiro de entrevista semiestruturada e gravador de áudio.

Foram realizadas três entrevistas semiestruturadas com os três participantes, separadamente, no local de trabalho de cada um. O ambiente escolhido para esses encontros foram propícios para uma troca de informações sem muitas interrupções, barulhos e outras situações que poderiam prejudicar o momento da entrevista.

\section{Procedimentos e análise dos resultados}

Primeiramente, foi feita a submissão do projeto de pesquisa ao Comitê de Ética em Pesquisa no Instituto de Ciências Humanas da UnB. Em seguida, entramos em contato com os psicólogos sujeitos da pesquisa para agendar as entrevistas. Posteriormente, essas entrevistas foram transcritas e os resultados foram agrupados em temas mais recorrentes, 0 que permitiu uma melhor análise interpretativa das respostas obtidas. 


\section{V - RESULTADOS E DISCUSSÃO}

Ao iniciar cada entrevista, o pesquisador esclarecia ao participante que se tratava de um diálogo aberto com o intuito de fornecer informações para atender os objetivos de uma dissertação de mestrado.

Os resultados foram agrupados em temas com significados relacionados às respostas dos três entrevistados.

\section{A escolha pela Psicologia}

Todos os entrevistados esclareceram que a escolha pelo curso de Psicologia se deu de maneira pessoal, sem interferência de amigos ou familiares. Um dos entrevistados mencionou o desejo dos pais para que ele fizesse outro curso, no entanto afirma que: "Fiz outros vestibulares por influências familiares, mas optei pela psicologia por anseio de compreender o ser humano".

Os entrevistados apresentaram certas semelhanças quanto aos motivos que os levaram a optar pelo curso de Psicologia. O interesse em compreender, ajudar e estar em contato com pessoas é bem presente nas falas apresentadas e na entrevista como um todo. Segundo Guggenbühl-Craig (1998), em determinadas circunstâncias e condições, o ser humano sente um desejo de ajudar seus semelhantes, e isso constantemente é percebido ao longo da história. Algumas áreas do conhecimento e, entre elas, a Psicologia é vista como sendo de ajuda. A institucionalização dessas áreas que buscam prestar apoio às pessoas e o querer ajudar é uma assertiva que se reitera fortemente entre candidatos a profissões tais como o serviço social e a psicologia.

Ao serem questionados sobre como iniciaram seus estudos e interesses em cursar psicologia, tivemos algumas das seguintes respostas: "Sempre gostei de ler, compreender indivíduos e seus comportamentos"; "O interesse em psicologia foi realmente ver que aqui eu poderia ajudar pessoas"; "Sempre tive a intenção de trabalhar com pessoas, ajudando e vendo uma melhora na qualidade de vida delas".

\section{O interesse pela psicologia do esporte e do exercício}

Seguindo o objetivo de compreender como os entrevistados percebiam o seu processo de tornar-se psicólogo do esporte, foi dada a abertura e a oportunidade para que expressassem sobre como havia sido esse processo desde o período de graduação universitária e até mesmo anteriormente a ele.

Durante as entrevistas, os três participantes declararam terem tido contato e interesse intensos com o esporte desde a infância, tanto como atletas e como expectadores. Ao longo da adolescência, praticaram atividades físicas de maneira regular, 
jogaram em times, participaram de campeonatos e isso se deu antes de ingressaram na universidade. "Ao entrar no curso já almejava trabalhar com o esporte, psicologia no contexto esportivo, porque durante toda a adolescência fui praticante assíduo de futebol de salão. Tinha dúvidas que a psicologia ia ajudar. Nunca cogitei em trabalhar em clínica, escola ou organizacional". Outro entrevistado comentou que: "Comecei a estudar línguas e o meu foco ainda não era totalmente a psicologia. Depois surgiu a ideia de fazer algo útil que eu pudesse ajudar as pessoas. Por acaso, acabei tendo uma competição esportiva, eu sempre adorei e fiz esportes, na semana do vestibular. E acabei optando por participar da competição. E depois de seis meses acabei me aproximando da psicologia, e quando fiz o vestibular no final do ano já optei pela psicologia"

A partir desses relatos, podemos observar que a escolha pela área da psicologia muitas vezes está ligada com as experiências pessoais ao longo da vida. Esses sujeitos expressam suas experiências com o esporte, o que pode ter influenciado na escolha de suas atuações no campo da psicologia do esporte e do exercício. No entanto, essas vivências não são suficientes para a formação do psicólogo do esporte. Segundo Rubio (2000), conhecimentos específicos da área são necessários para essa formação.

O contato com o esporte não se restringiu apenas a momentos anteriores ao ingresso na universidade, mas durante a graduação também, como podemos observar nas seguintes frases: "Entrei na UnB em 1994. No primeiro semestre fui disputar um campeonato internacional de futebol de salão". Foi evidenciado mais de uma vez que os entrevistados já tinham um contato com o esporte anterior ao começo do curso de graduação.

Um dos entrevistados disse que conheceu sobre a possibilidade de trabalhar associando psicologia e esporte a partir de uma palestra oferecida pela empresa júnior de psicologia da UnB, Praxis: "Na primeira semana tive uma maratona de palestras. Foram oferecidas pela "Praxis", sobre as diversas áreas da psicologia, e me apresentaram a psicologia do esporte. Isso foi no meu primeiro semestre, aí pronto. Eu me apaixonei e passei o curso inteiro já sabendo o que eu queria".

\section{Tornar-se psicólogo do esporte no curso de Psicologia da UnB}

Como vimos anteriormente, no capítulo 2 desta dissertação, o Projeto Pedagógico de Psicologia da UnB (PPC IP/UnB, 2013) pontua a formação generalista do psicólogo. Esse objetivo é percebido pelos entrevistados e podemos exemplificar com esta fala de um deles: "Acho que o IP tem a intenção de fornecer um curso generalista e você depois deve ir buscar uma formação específica". 
A concepção curricular flexível, associada a uma ampla oportunidade de envolvimento de estudantes de graduação em projetos de pesquisa, de extensão e uma política objetiva de integração das atividades têm conferido ao curso de graduação do IP as condições essenciais para a realização dos objetivos de uma formação profissional diferenciada.

Os três entrevistados relataram possuir a habilitação dupla, de Psicólogo e de Licenciatura, o que é permitido pelo curso da UnB. É dado ao aluno a liberdade e independência de construir o seu fluxo de disciplinas ao longo da graduação, entre disciplinas obrigatórias, optativas e de módulo livre. As disciplinas obrigatórias fornecem uma visão geral e ampla das possibilidades que a Psicologia oferece, e o aluno é capaz de decidir seus caminhos de maior interesse ao longo de sua formação. Essa formação curricular é percebida nas seguintes falas dos entrevistados: "Fiz pesquisas na área hospitalar, psicologia ambiental e organizacional. Eu transitei bem nas áreas e tive muita consciência quando mantive minha decisão de permanecer com o objetivo de trabalhar com psicologia do esporte". "Inclusive, durante todo o curso, eu passei por diversas áreas e campos da psicologia, e nenhuma ligada à psicologia do esporte. E isso tudo apesar de ter estudado bastante e ter ido em diversas palestras em outras universidades e outras cidades".

O entrevistado que primeiro ingressou na UnB e se formou em 2004 não teve a oportunidade de conhecer a área da psicologia do esporte no IP, dado que a disciplina foi criada apenas em 2008. Ele relatou seu envolvimento na área a partir do contato com uma disciplina da faculdade de Educação Física da UnB: "O único momento que se aproximou do que eu queria foi ao cursar uma disciplina no departamento de educação física - FEF, que fiquei sabendo por contato de amigos do futebol, os quais eram muitos do curso de educação física. Foi o único momento que tive oportunidade, em nível de graduação, de estar em contato e discutir sobre a psicologia do esporte". Esse fato remete-nos à história da origem da psicologia do esporte ligada à Educação Física, como vimos no primeiro capítulo. Notamos que mudanças significativas ocorreram desde a sua formatura para os dias atuais. No entanto, essas mudanças não devem significar um distanciamento da Psicologia com a Educação Física, mas ao contrário, o desenvolvimento da interdisciplinaridade muito importante para a área.

As trocas de conhecimentos entre psicólogos e educadores físicos são vistas com bons olhos para o avanço da área, sempre levando em consideração principalmente o indivíduo e suas subjetividades, e não deixando de lado as suas interações nos ambientes o qual está inserido (Rubio, 2001).

A busca de um conhecimento mais específico partiu diretamente dos próprios profissionais, pelo seu interesse ou necessidade, e, talvez, seja exatamente essa a 
proposta elaborada para a formação em psicologia, sempre dando continuidade a este processo de capacitação e enriquecimento teórico. "Na psicologia do esporte eu não vi nada claro ou aparente pra mim assim que eu formei. Além que eu não me via com maturidade suficiente para correr atrás e buscar meu espaço na área. Eu estava totalmente perdida. Aí fui convidada por um colega que esteve presente na minha graduação a fazer um estágio voluntário com Kung Fu, mesmo depois de formar. Foi minha primeira experiência fazendo intervenções com a equipe, e foi maravilhoso, foi incrivel".

Sobre a importância da formação em psicologia, mesmo que generalista, percebemos que ela permite a atuação na área da psicologia do esporte sempre em processo de tornar-se. Podemos exemplificar essa idéia a partir da frase de um dos entrevistados: "Eu diria que a graduação em psicologia foi essencial. Sem ela eu não estaria onde estou. Mas acho que faltou bastante uma vinculação aos ensinamentos no contexto esportivo. Essa conexão eu tive que fazer na pós-graduação. Totalmente por conta própria. Ver os conceitos que aprendi na psicologia e fazer um 'transfer' para o esporte, e isso é muito difícil".

A formação generalista fomentada pelo Plano de Diretrizes Curriculares em Psicologia nos faz refletir sobre as possibilidades para a atuação como especialista em uma determinada área, no nosso caso, a psicologia do esporte. Dessa forma, espera-se que seja dada aos estudantes de Psicologia a oportunidade de discutir essa formação. Eles devem se sentir acolhidos para que um direcionamento aos seus questionamentos seja desenvolvido em relação ao momento após a formatura. O curso de Psicologia na UnB ainda não abre tantos espaços de discussão para a área do esporte, como em outras áreas mais tradicionais. Um dos entrevistados evidencia esse fato na seguinte fala: "Eu sentia muita falta de espaços de discussão. Uma coisa é você ter 3 ou 4 pessoas discutindo sobre algo, mas sempre as mesmas dificuldades. Lógico que é muito melhor que estar sem ninguém, mas teria sido bem mais rico e produtivo que tivessem mais pessoas interessadas, ou que soubessem que psicologia do esporte existe".

Os entrevistados relataram que não se sentiram confortáveis para atuar como psicólogos do esporte logo após a graduação em psicologia. Eles disseram que só foi possível se sentirem mais seguros com cursos após a graduação: "Os conhecimentos da pós que me trouxeram uma psicologia aplicada, aqui que consegui aprender até a como estudar, a me ancorar na psicologia do esporte". "Durante a pós-graduação eu não me sentia confortável em prestar nenhum serviço a ninguém". "Eu só me senti seguro de prestar um serviço de qualidade após a minha especialização".

O processo de tornar-se para Rogers (?) evidencia sua compreensão do processo de tornar-se humano, do ser e do estar no mundo tão singular e potencialmente mutável de 
cada um. Para os entrevistados, percebemos esse processo de tornar-se psicólogo do esporte na atuação profissão e nas experiências subjetivas de cada um. Esse processo de vir a ser está sempre em construção que vai além da formação nas disciplinas de graduação. Um dos entrevistados ilustra essa idéia com a seguinte frase: "Eu acho que depois do ano inteiro de intervenções com os alunos do Kung Fu, e tendo as orientações e ensinamentos dos meus colegas que já eram mais experientes e estavam no meio há mais tempo, fui me sentindo mais como uma psicóloga, e fui me encontrando".

Outro entrevistado se expressou sobre essa questão, dizendo que: "Eu me senti como um psicólogo do esporte que eu me tornei, foi no mestrado. E teve um momento que foi fundamental para isso, porque ninguém nasce como psicólogo do esporte, e esse momento foi quando comecei a trabalhar como docente em nível superior. Eu comecei a dar aula em psicologia do esporte para educadores físicos. $O$ fato de dar aula me colocou em diversas situações que eu precisei estudar e me desenvolver, e isso foi me dando um 'background' para o meu trabalho como psicólogo do esporte".

O outro entrevistado relatou que: "Após a especialização também não me sentia como psicólogo, porque apesar de eu estar mais confiante e me sentindo apto a trabalhar com atletas e a psicologia esportiva, ainda estava tudo muito fresco na minha cabeça. Eu ainda não havia assimilado como utilizar dos ensinamentos para uma prática profissional. Durante o mestrado, trabalhando com a psicologia esportiva e o futebol, com essa minha vivência com atletas e jogadores de futebol, que foi de fato que aceitei os desafios, o trabalho remunerado, as discussões, textos, e aqui me senti dentro de um processo que eu estava me formando um psicólogo do esporte. Isso se deu comigo no mestrado". Aqui dois pontos são de extrema relevância de serem verificados. O primeiro, de como o trabalho estava formando o profissional em psicólogo do esporte e do exercício. E o segundo, que a formação generalista promovida pelo curso e defendida pelas DCN, auxiliou para que esse psicólogo pudesse dar seus primeiros passos em busca de sua área de afinidade e uma capacitação de atuação. Porém, ainda necessitando de cursos após a graduação para que esse processo ocorresse.

A partir das respostas dos entrevistados, foi possível verificar que eles adquiriram vários conhecimentos de atuação na psicologia do esporte durante as atividades profissionais. Também podemos observar que outras relações favorecem esse processo de tornar-se psicólogo do esporte, como o relatado por um entrevistado: "Depois foram os colegas do curso que me ajudaram bastante. Eles que me falavam sobre congressos, livros e autores. A internet me auxiliou bastante, e os congressos que fui também me direcionaram bastante. E a partir daí fui me descobrindo, descobrindo a psicologia do esporte e modificando sempre a minha maneira de ver a psicologia do esporte. E cada vez 
que eu ia pra eventos eu ia conhecendo mais pessoas e elas iam me ajudando. Não foi nada isolado".

O processo de tornar-se psicólogo do esporte e do exercício, para os entrevistados, esteve sempre muito interligado com a atuação profissional na área. Os primeiros trabalhos realizados ainda eram permeados de inseguranças, devido a ausência de experiência profissional consistente, mas ao desenvolverem suas atividades, com os conhecimentos adquiridos, e constatando resultados, aos poucos ia fazendo sentido a eles que estavam tornando-se quem eles almejavam ser. "O momento que mais caiu a ficha que eu era um psicólogo do esporte foi cinco anos depois de formar em psicologia, quando fiz uma intervenção no meu trabalho atual. Aí volto àquela ideia de me sentir ajudando. Essa intervenção era uma questão muito problemática que a gente estava enfrentando aqui no trabalho e com muitos atletas. Mas conseguimos lidar de uma maneira muito boa e os resultados foram ótimos. Nesse momento, eu percebi que era isso que eu queria, era pra isso que eu estava estudando. Esse resultado foi tudo que eu me esforcei tanto por tantos anos. E foi nessa hora que tudo fez sentido, tudo pelo que eu tinha corrido atrás".

O processo de tornar-se representa uma possibilidade de se sentir confiante no que se é e no que se é capaz de realizar. Não existe uma formação acabada, o profissional está sempre em um curso contínuo de transformação: "Eu ainda vou para palestras, ainda vou para congressos e procuro espaços que eu possa discutir com colegas. Hoje eu busco discutir bastante com meus amigos e colegas do trabalho que tenho muito contato. Eu ainda leio bastante e estou sempre comprando livros".

Esse é o processo de tornar-se pessoa para Rogers (sem data) que envolve estar sempre disposto a enfrentar novas situações, desafios, mudanças, que está aprendendo, ganhando confiança, e descobrindo novos aspectos sobre si mesma. "Eu fiz uma palestra ano passado com um colega e foi sensacional. Porque foi algo de muita troca, foi aprendizado puro. Você ter que se preparar pra ensinar algo para alguém, você tem que se preparar bastante e estudar muito. Você tem uma responsabilidade muito grande. Quando você está sendo visado, tem uma cobrança, te eleva de forma exponencial. Esses espaços que precisamos tomar a frente, pra mim são os momentos que eu mais aprendo. Porque você tem que se posicionar e explicar de determinada maneira para fazer com que muitas pessoas diferentes entendam o seu ponto de vista. Tem que fazer sentido para públicos diferentes".

Quando questionados sobre o momento que sentiam que haviam se tornado psicólogos do esporte, os entrevistados declararam que foi apenas depois de alguns anos de prática. Quando estavam se sentindo seguros de quem eram, o que faziam e como faziam. Esse momento não se deu para nenhum deles durante ou logo após a graduação em psicologia, mas depois de estudos de pós-graduação e práticas profissionais: "Na minha 
pós-graduação, aí sim entrei na psicologia do esporte de verdade. Fiz cursos onde atuei bastante. Cursos em Brasília e em São Paulo, na própria UnB, somente na FEF. Psicólogos, educadores físicos, todos juntos, fazendo estágios, tendo práticas em campo, trabalho final. Tudo isso em nível de especialização". Outro entrevistado relata que: "Mas no final do curso de psicologia eu estava totalmente perdido. Acho que porque o mercado ainda estava muito perdido e tinha poucas pessoas mostrando seus trabalhos em psicologia esportiva".

Os três entrevistados declararam em algum momento que o processo de tornar-se psicólogo do esporte se deu com um tempo considerável após a formação em Psicologia. Que ao final da graduação não se sentiam como psicólogos, nem que poderiam fazer um bom trabalho ou estar preparados para atuar em alguma área. Os primeiros trabalhos foram fazendo com que uma confiança fosse conquistada, e aos poucos esse sentimento foi surgindo: "Demorou uns anos depois de me formar pra eu achar que poderia atuar com psicologia. Eu me senti mais seguro". "Depois de um tempo nesse trabalho que me senti encabeçando a causa, imersa no mundo da psicologia esportiva e dando os primeiros sinais de segurança de estar podendo fazer um bom trabalho. E só aqui no meu trabalho que dei minha cara a tapa pra aprender na prática".

Associando o processo de tornar-se psicólogo do esporte como algo contínuo e fluido durante a formação acadêmica e profissional, a educação permanente caraterizada nas DCN (2011) visa à possibilidade e à capacidade do estudante de Psicologia e a pessoa formada de sempre se enriquecer de aprendizados da área.

Acreditamos que o processo de tornar-se psicólogo do esporte e do exercício parte de uma interação com a atividade ao desempenhar o papel profissional, uma relação dialética, já que no contato com o ambiente de trabalho se dá a percepção dessa própria construção da pessoa. Nesse ponto, parece ser de grande importância perceber que Psicologia da UnB poderia ou até deveria ser criadora de espaços de reflexão para os futuros psicólogos, e isso nas mais diversas especialidades em que esses desejem atuar. Sugere-se que a Psicologia como um curso busque sempre investigar e estudar situações que possam auxiliar os psicólogos que demonstram inseguranças e carências ao desenvolver seus trabalhos em relação ao seu espaço no mercado de trabalho e suas capacitações, a fim de estar sempre se desenvolvendo com a formação de seus próprios profissionais.

\section{Tendências da psicologia do esporte e do exercício}

Os entrevistados também expressaram suas idéias sobre o aumento de pesquisas e demandas na sociedade em relação à psicologia do esporte e do exercício. Segundo Valdés (2000), a década de 90 trouxe significativas mudanças nos ambientes universitários 
com as primeiras palestras e congressos de grande repercussão nacional, mas mesmo hoje, ainda estamos relativamente atrasados em relação aos países desenvolvidos. Muitas vezes, a importância da área surge nos momentos de fracassos em competições. Isso se evidencia na fala de um dos entrevistados: "No discurso é muito bonito, a importância da psicologia do esporte aparece na mídia, mas isso se dá principalmente nas derrotas. Atinge o grande público nos grandes fracassos, aí a mídia se fortalece. Quando o Brasil toma 7x1 e vem todo mundo dizer que é psicológico. Isso reverbera muito mais que sobre a equipe alemã que foi campeã e veio com uma delegação muito bem organizada e com 12 psicólogos do esporte. Esses países desenvolvidos já se assentaram sobre a importância da psicologia do esporte e trabalham com ela".

Nessa mesma década de 90, surge a disciplina específica na área, sendo oferecida em algumas universidades do Brasil (Rubio, 2000). Isso pode ter auxiliado a não só despertar o interesse dos estudantes, mas como fomentar possibilidades de pesquisas, de experiências e práticas no campo do esporte e do exercício.

O avanço científico na área também foi destacado pelos entrevistados: “Em 2004 eu só encontrava periódicos em inglês e espanhol. Hoje já temos bastante material em português e sendo produzido aqui mesmo no Brasil. Houve um incremento significativo na importância da psicologia do esporte. E ainda mais nos últimos anos com a realização desses grandes eventos que o Brasil veio a ser sede, Copa do Mundo e Olimpíadas".

Becker Jr (2000) afirma que as pesquisas relacionadas à psicologia do esporte e do exercício devem ser estimuladas para o avanço do campo. Quanto mais publicações forem feitas, possivelmente maior será o alcance de suas propostas. Deve-se ampliar e auxiliar as pesquisas, já que estas, no seu ponto de vista, são o que mais pode fortalecer o desenvolvimento das especialidades em ascensão. Para isso, deve-se ter um maior número de profissionais e especialistas na área acadêmica.

Durante uma das entrevistas, veio à tona a dificuldade de se trabalhar com psicologia do esporte e do exercício, ainda por falta de um conhecimento de quem forma em áreas que atuam com o esporte: "No Brasil a gente já passou da fase se a psicologia do esporte é importante ou não, mas pouco ainda se coloca na prática. No discurso ela é importante, mas na prática ainda é um luxo que os times não querem arcar. O primeiro processo que eu vejo para modificar esse cenário é de incentivar aos cursos de graduação a inserirem a psicologia do esporte no seu contexto". Outro entrevistado acrescenta que: "O esporte brasileiro precisa avançar em termos de especialização. As nossas federações brasileiras e o compromisso com a ciência estão muito atrás dos países desenvolvidos. Muito ainda está no empirismo, os técnicos fazem o que faziam com eles enquanto eram atletas. O avanço está bem mais lento que em outros países". 
Os temas em pesquisas na psicologia do esporte e do exercício ainda são guiados pela demanda das instituições esportivas que fomentam o seu desenvolvimento, e continuam mais voltados para tecnologias e rendimento. Essa vem sendo a tendência dos estudos na área, em relação ao alto desempenho dos atletas profissionais (Rubio, 2000). Quem atua na área percebe um maior investimento no cenário de atuação profissional: " $E u$ vejo essa formação muito ligada com o desenvolvimento do esporte no Brasil nos últimos anos. Vejo um investimento maior no esporte tanto por parte do governo como de iniciativas privadas. Copa do mundo, Olimpíadas e tals. Eu ando percebendo não só um avanço de estímulo financeiro, mas na capacitação de profissionais e pesquisas. E aí surgem muitos outros profissionais trabalhando juntos e não só mais o técnico".

As demandas que surgem no contexto esportivo e da atividade física favorecem as investigações na área da psicologia do esporte e do exercício, assim como nas Ciências do Esporte como um todo (Viveiros, Moreira, Bishop, \& Aoki, 2015).

Fiorese, Lopes \& Andrade (2013) investigaram como vinham se dando as publicações relativas à psicologia do esporte e do exercício nos dez anos antes que antecederam o seu estudo. Foram utilizadas as publicações encontradas no Scopus e no Scielo, nas suas respectivas bases de dados. Foram considerados para a análise os periódicos brasileiros da Psicologia e da Educação Física. A pesquisa constatou que foram produzidos 377 artigos no período de 11 anos (2002-2012). Esses artigos foram produzidos dentro de programas de pós-graduação, sendo elaborados tanto por discentes quanto por docentes, ou ambos. Um dado relevante e otimista para o estudo foi que nos últimos quatro anos da análise, o crescimento do número de publicações foi bastante significativo. Foi constatado um dado em relação à região de onde vinha o maior número de artigos. $A$ predominância foi das regiões mais ricas do país, sudeste e sul. A grande maioria, superior a $80 \%$ da amostra era de periódicos da Educação Física, o que pode demonstrar que a Psicologia ainda está buscando seu espaço na área. Os temas mais tratados foram motivação e liderança, e a abordagem quantitativa foi a mais utilizada.

\section{Especialização em psicologia do esporte e do exercício}

Segundo Rubio (2007), parte dos avanços que se deu nos últimos anos foi devido à regulamentação, no ano de 2007, do título de psicólogo especialista em psicologia do esporte pelo Conselho Federal de Psicologia. Esse momento demonstraria o interesse e a necessidade de uma nova estruturação para um melhor avanço da área.

Uma das possibilidades propostas para o desenvolvimento da psicologia do esporte e do exercício seria de, que em algum momento, os cursos de Psicologia no Brasil inserir a disciplina específica nos seus currículos. Isso ocasionaria um aumento da visibilidade não só dentro da profissão, mas na área em sua totalidade (Abdo apud Rubio, 
2000). Os alunos ao terem um contato especializado dentro da universidade teriam a possibilidade de dar continuidade aos seus estudos relativos ao tema, caso fosse de interesse. E esse primeiro contato, seja de orientação ou direcionamento seria primordial, como afirma um dos entrevistados: "Tentei começar um grupo de estudos em psicologia do esporte com alguns amigos, mas sem sucesso porque não tinha um norte, a gente não se encontrava no tema, e nenhum professor dava um suporte para direcionar esse estudo".

Outro ponto levantado nas entrevistas foi que seria ainda mais enriquecedor para a área, que esse suporte profissional aos alunos fosse feito por alguém com experiência ou com especialização na área. Uma fala de um dos entrevistados ilustra essa sugestão: "Colocar o psicólogo clínico pra tampar um buraco na área da psicologia do esporte traz uma série de problemas. É muito complicado colocar alguém que não é da área para dar aula. Acaba ficando algo muito superficial e desvinculado da realidade. Tem que entrar na cultura brasileira, e nas outras áreas que envolvem esporte, indivíduos, atividades físicas, a relevância de se trabalhar com a psicologia do esporte como uma necessidade, e não um luxo. A nossa formação na graduação tem que melhorar muito, e integrar com as outras ciências do esporte".

Angelo (2003) acredita que o psicólogo do esporte e do exercício não pode se eximir de conhecer os valores culturais, sociais e os fundamentos de outras ciências do esporte, no que for possível. Sendo assim, um psicólogo especialista provavelmente estaria com melhores possibilidades e condições de promover os ensinamentos propostos. Um dos entrevistados pontua que acredita que as aulas da disciplina relativa à psicologia do esporte e do exercício deveriam ter um professor que fosse da área: "Eu acho que deveria ser oferecida por um professor especialista no assunto também. Porque eu entendo que sempre foi ofertada por pessoas que lutavam pela causa e que eu admiro bastante, mas que estão mais engajadas em outras áreas, e aí se perde muita coisa. Acho que um professor lá dentro dos colegiados ou do departamento, alguém que estivesse disposto mesmo de fortalecer a causa, correr atrás, poderia fortalecer bastante a área".

Dois dos entrevistados colocaram seus pontos de vista, por meio de relatos pessoais de suas experiências na graduação, em relação à importância que eles deram de ter a oportunidade de presenciar o começo da oferta da disciplina psicologia do esporte e do exercício na UnB: "Eu tive a sorte de conseguir pegar a disciplina de psicologia do esporte no meu último semestre da graduação. Eu acho que deveria ser uma disciplina ofertada pelo menos uma vez por ano, pela demanda mesmo. Acredito que tenha sido a única vez que foi ofertada nos meus 5 anos de faculdade". "Acho que todos deveriam ter pelo menos umas 3 oportunidades ao longo do curso pra pegar a disciplina. Porque as vezes o horário é incompatível e você perde a única oportunidade, se der sorte de ter". 


\section{Sugestões para o avanço da área}

Os entrevistados falaram do processo de tornar-se psicólogo do esporte, deixaram clara a importância da inserção na prática da atividade profissional. Diante disso, os sujeitos participantes foram questionados se eles tinham alguma sugestão de como poderia ser aprimorada a formação dos alunos interessados em trabalhar com a psicologia do esporte e do exercício.

Dois participantes mencionaram a importância de se ter estágios na área e como isso poderia auxiliar na compreensão e integração com os conhecimentos teóricos. Como pode ser percebido em suas falas: "Mas o que acho o mais importante, de imediato, era promover estágios na área. Um estágio específico. Algo consolidado, com discussões, práticas, horário próprio. Uma atenção específica. O estágio é muito bom pra discutir, é super rico, você percebe as demandas na prática. Coloca a teoria em jogo". "Senti falta de projeto de pesquisa e estágio. Todas as minhas pesquisas e estágio foram na clínica porque não havia disponibilidade". Os estágios buscam fazer com que os formandos entrem em contato com situações e em ambientes que provavelmente vão ter que enfrentar futuramente, e funcionando como um momento de aprendizado, e, sob supervisão, permitem que habilidades e atitudes profissionais sejam construídas (DCN, 2004).

As instituições de graduação em Psicologia, com o objetivo de estar sempre incentivando espaços que irão produzir reflexões, devem também favorecer diversificados trajetos e oportunidades de escolha aos estudantes durante sua formação no curso. Esse aluno terá a chance de caminhar em diversas áreas e campos que essa ciência possui, e assim poderá ter de maneira pessoal e objetiva, o seguimento que deseja no seu processo de construção de conhecimento (DCN, 2011).

O estágio supervisionado na UnB vem como uma das maneiras de assegurar com que esse formando tenha um contato diferenciado, em situações e contextos da Psicologia. De acordo com o artigo 21 das DCN de 2011, essas formas de contato com a prática assemelham-se a ações que os profissionais lidam no contexto de trabalho, e ao serem realizadas pelos estudantes, irão desenvolver conhecimentos, habilidades e atitudes ricas na formação. Um dos entrevistados relata a importância de serem oferecidos estágios nas mais diversas áreas da psicologia, o que corrobora com a formação generalista da Psicologia da UnB, e vai além, esclarecendo que os alunos devem ter a oportunidade de escolha de quais estágios irão fazer: "O projeto de se dar uma formação generalista contribui para que certas portas se mantenham abertas, mas que não necessariamente precisam ser adentradas. Para se ter uma boa formação, o aluno tem que poder ter escolhas, não só ir pegando as matérias e estágios que oferecem. Nem a instituição pode oferecer dois ou três áreas pra estágio e achar que está dando uma formação ampla". 
Um dos entrevistados relatou que não teve oportunidade de participar de atividades diferenciadas da clínica no contexto fora de sala de aula, o que causou certo incômodo tanto durante a graduação como após a sua formação. Esse sentimento é trazido na seguinte fala: "Meu único contato com a parte prática de psicologia do esporte durante a graduação foi na Faculdade de Educação Física, e foi muito superficial. Senti falta de projeto de pesquisa e estágio na Psicologia. Todas as minhas pesquisas e estágio foram na clínica porque não havia disponibilidade". Esse relato demonstra o interesse de que sejam promovidas práticas diversificadas dentro dos departamentos do IP.

Para um dos entrevistados, a psicologia do esporte e do exercício, assim como outras áreas da Psicologia como um todo, ainda é muito desconhecida pelos alunos de graduação. Nesse sentido, a fim de enriquecer e promover áreas menos divulgadas deveria ser oferecido pelas universidades pelo menos um mínimo contato para a abertura do leque de possibilidades de estudos e atuação do psicólogo. A sua fala exemplifica esse pensamento: "A primeira coisa que eu faria era divulgar mais a psicologia do esporte nos departamentos de psicologia. Que fossem promovidas palestras sobre as áreas que a psicologia atua. Não precisam ser disciplinas, mas para os alunos realmente poderem conhecer os mais diversos campos que os psicólogos atuam. E que não são só as disciplinas que eles tão vendo ao longo do curso".

Um dado que traz questionamentos em relação a como se vem dando importância e abrindo espaços para o desenvolvimento da psicologia do esporte e do exercício foi pontuado por laochite, de Almeida Nogueira \& de Aragão Sadalla (2004) que afirmam que $82 \%$ dos estudantes de educação física do país em algum momento aprendem conteúdos relativos a essa especialidade. Apesar de não se ter o dado que diz respeito aos estudantes de Psicologia, de acordo com um entrevistado, existe ainda uma falta de promoção da área dentro UnB e em outras universidades: "Nos anos que estive na UnB, nós só tínhamos uma disciplina na universidade, que era ofertada na FEF, por um educador físico e ao que me parece, por um vácuo que psicologia deixou".

Foi sugerido por um entrevistado que mais pesquisas deveriam ser feitas com a ideia de que pudessem produzir e validar testes a fim de auxiliar os trabalhos dos psicólogos do esporte. Estes sempre traziam instrumentos de outras áreas da psicologia e tentavam adaptar no que fosse possível. Como é feita essa adaptação pode ser percebida no relato: "Ver os conceitos que aprendi na psicologia e fazer um "transfer" para o esporte, e isso é muito difícil. Por exemplo, eu não conheço nenhum teste psicológico que seja vinculado ao esporte. Então nem sempre usar o adaptar seria satisfatório. A gente trabalha com questionários desenvolvidos por nós mesmos. Alguns já têm até questionários validados para um esporte, mas se mudou o esporte, já não vale. Então eu mesmo crio 
meus instrumentos de anamnese para utilizar no meu trabalho, e o que me ajudou nessa capacidade de fazer isso foi a minha formação em psicologia. Isso me auxiliou bastante para eu avaliar os atletas".

Corroborando com o relato apontado acima, Rubio (2007, p.3) também fala dessa dificuldade na área:

Diferentemente de outras áreas da Psicologia nas quais já foram desenvolvidos e validados um grande número de instrumentos de avaliação, a área de esportes ainda carece de referencial e conhecimento específicos para investigação, e isso tem acarretado alguns problemas bastante sérios. Um deles é a utilização de instrumentos advindos da avaliação em psicologia clínica ou da área educacional com finalidades específicas, como detecção de distúrbios emocionais, perfis psicopatológicos ou quantidade de inteligência, próprios e necessários para os fins que foram desenvolvidos. O outro é a importação de instrumentos de psicodiagnóstico esportivo desenvolvidos em outros países e aplicados sem adaptação à população brasileira, que apresenta condições físicas e culturais distintas de outras populações. Diante disso, questões de ordem ética têm emergido para reflexão sobre o uso e abuso de resultados obtidos por meio de instrumentos de avaliação psicológica no esporte.

A respeito do mencionado em relação à atividade clínica, deixamos claro que entendemos que a Psicologia do Esporte é diferente da Psicologia Clínica com praticantes de atividades físicas. Porém, é possível se utilizar o olhar clínico desenvolvido pelo psicólogo ao longo de sua formação para investigar as influências dos comportamentos do sujeito no contexto esportivo.

O Conselho Federal de Psicologia (CFP 13/07), ao caracterizar as atribuições condizentes ao psicólogo especialista em psicologia do esporte e do exercício, considera que a aplicação de instrumentos que irão determinar perfis de praticantes de atividades físicas dentro do contexto da prática esportiva, faz parte da atuação desse psicólogo. O que de certa forma nos leva a crer que as adaptações desses instrumentos, advindos de outras áreas da Psicologia, e feitos por profissionais que atuam no campo esportivo, são os primeiros passos para o desenvolvimento específico dessas técnicas.

Uma crítica feita por um dos entrevistados relaciona-se à falta de interação entre departamentos da Universidade de Brasília: "Sempre encontrei muitas dificuldades de 
interação entre o Instituo de psicologia e a Faculdade de educação física. Não sei dizer por quê. Mas isso prejudica a psicologia do esporte como um todo". Sabendo que a psicologia do esporte e do exercício é uma área de conteúdos interdisciplinares, a comunicação que poderia ser feita entre diferentes cursos de graduação que buscam estudar essa área, provavelmente traria avanços significativos para o seu futuro. "A Psicologia do Esporte contribui por ser uma ciência que começou a ser desenvolvida tendo como base a idéia de que o profissional que trabalha com Educação Física deveria estar familiarizado com a Psicologia e os benefícios psicológicos que poderiam vir da prática de atividade física e esportiva" (Matos \& Andrade, 2011, p.140).

O projeto pedagógico do curso de graduação em psicologia (2013) busca fazer essa conexão entre os departamentos, institutos e faculdades na UnB. Um aluno poderia assistir aulas em outras unidades, e se essas aulas apresentassem compatibilidade de competências para o desenvolvimento do estudante dentro do seu curso de origem, ou como uma formação pessoal, as horas seriam integralizadas para o seu currículo e auxiliaria para complementação dos créditos de sua formação. A UnB de certa forma já incentiva essas condutas há anos quando adota o sistema de disciplinas optativas e de módulo livre.

Um entrevistado relatou a importância e a dificuldade de se ter diferentes profissionais da área acadêmica trabalhando juntos para que a psicologia do esporte e do exercício se consolide cada vez mais nas universidades brasileiras. No seu relato é trazido que a UnB ainda não apresenta uma ligação ideal entre os seus departamentos: "Deve-se ter a capacidade interdisciplinar com outras áreas do conhecimento e trabalhando mutuamente. Essa porta, para interagir entre as duas graduações, Psicologia e Educação Física, estava sempre fechada, a meu ver. Parecia, na minha opinião, que os psicólogos viam que apenas eles estavam no direito e na capacidade de desenvolver a psicologia do esporte. Até porque é uma especialidade do psicólogo".

Uma das sugestões deixadas era a de que, apesar de ser uma especialidade do psicólogo, isso não impediria que outros profissionais pudessem ministrar aulas para alunos de psicologia. Assim como psicólogos também poderiam oferecer aulas para alunos de outros cursos de graduação. A sugestão apontava que deveria ser ofertada uma disciplina de psicologia do esporte e do exercício por professores de departamentos diferentes, com alunos de cursos diferentes, para se assemelhar ainda mais e já contextualizar como seriam feitos os trabalhos depois da formação acadêmica: "Para mim, deveria haver um disciplina compartilhada entre professores da FEF e do IP, com alunos de ambos os cursos, como de fato é na prática. Acho que isso seria bastante enriquecedor para todos".

Quando nas entrevistas se levantava críticas ou sugestões, era comum que os entrevistados colocassem as dificuldades que passaram, com o intuito de auxiliar os futuros 
psicólogos que desejem atuar com a psicologia do esporte e do exercício. Uma crítica, porém se destacou entre as demais, pois esta trazia um ponto que julgava negativamente outros psicólogos: "Tem muitos psicólogos por aí trabalhando com modalidades que não possuem o menor conhecimento. Isso só prejudica os atletas e queima o filme dos psicólogos para a comissão do time. O psicólogo tem que conhecer do esporte que ele tá trabalhando. Às vezes ele só pensa no salário". Rubio (2007) escreve sobre como a utilização de psicodiagnósticos é utilizada no contexto da psicologia do esporte e do exercício. Em seu artigo, a autora coloca diferentes interpretações para as intervenções em esportes coletivos, individuais, de alto rendimento, escolares, entre outros. Sendo assim, fazendo-se perceber como o conhecimento do tipo de atividade física e o contexto em que ela ocorre são relevantes para uma boa intervenção do psicólogo.

O Código de Ética do Psicólogo (Lei 5.766/1971) traz que o trabalho desenvolvido pelo profissional em Psicologia deve ser de alta qualidade, baseado em evidências científicas e padrão ético. No contexto da psicologia do esporte e do exercício, o psicólogo deve refletir sobre as suas limitações para atender os padrões éticos e morais sustentados. Um dos entrevistados apoia esse ponto e esclarece de maneira mais objetiva. "Agora se você tem um conhecimento zero sobre determinada atividade física, aceitar trabalhar com esses atletas, na minha opinião, é algo muito antiético. Essa é um postura minha, eu só entro se tiver um mínima propriedade. Até porque são muitas modalidades e é impossível trabalhar com todas. Quem vive da psicologia do esporte acaba por selecionar seus campos de atuação. Como qualquer outro psicólogo de outra área. Você sempre se aproxima de uma modalidade".

É esperado de um psicólogo do esporte que este consiga articular aquilo que aprendeu durante a sua graduação com a realidade que encontra nas suas atividades profissionais. Além disso, ter a capacidade de apresentar uma postura segura, confiante e crítica diante de suas experiências durante seus trabalhos. Percebemos com esta pesquisa, que esse é um objetivo que ainda não foi alcançado pelos psicólogos que atuam com a psicologia do esporte e do exercício. Os relatos trazidos durante as entrevistas apontam ainda certas carências, inseguranças, dificuldades em relação as suas formações e atuações: "Eu formei em 2008 e terminei o mestrado em 2014. Meus últimos estágios foram na clínica, mas quando eu formei, passei um tempo matutando ir morar em São Paulo só pra fazer uma especialização. Mas acabou ficando difícil de ir e optei para fazer outras coisas porque estava super perdido na psicologia e ainda mais na psicologia do esporte".

Uma opinião de um dos entrevistados foi construída graças à possiblidade do surgimento de novos assuntos e elaborações em entrevistas semiestruturadas que analisam aspectos qualitativos e sempre buscam deixar abertas as possibilidades. Esse entrevistado, ao falar sobre seu percurso de estudos ao longo da graduação, relatou que 
sentiu certa frustração por não ter conseguido se aperfeiçoar nos ensinamentos da psicologia do esporte e do exercício enquanto estava na UnB: "O meu percurso de graduação foi tradicional como de qualquer outro psicólogo. Bem que tentei estudar mais sobre psicologia do esporte, mas não consegui. Saí de lá igual a todo mundo".

Propomos então, que seja prestado um apoio, suporte e incentivos durante as graduações generalistas em Psicologia. Esses atributos podem se dar por meio das aulas, palestras, seminários, colóquios, encontros estudantis, entre outros, com o objetivo de promover aos alunos uma abertura para caminhar nos diversos campos e áreas da Psicologia. Faz-se coerente que o aluno busque dar seus passos com autonomia, mas a abertura das portas não esteja restrita às áreas já consolidadas dentro do curso.

Finalizando, seria construtivo sempre haver reformulações, quando possíveis, nas disciplinas dos cursos de Psicologia, no sentido de adequá-las às demandas das realidades sociais, políticas que o discente irá enfrentar, bem como estimular esse estudante a confrontar o que está sendo aprendido com as situações de suas futuras pretensões profissionais. 


\section{VI - CONSIDERAÇÕES FINAIS}

O esporte nos dias atuais não está apenas associado à realização de uma atividade física com o intuito de promover saúde, ele vai muito além. Os exercícios físicos, as atividades físicas e o esporte podem ser considerados formas de representação cultural e social. Atletas profissionais nos dias atuais, muitos deles, vivem 24 horas por dia se dedicando para terem o maior rendimento possível. O esporte promove empregos para atletas, técnicos, preparadores físicos, educadores físicos, psicólogos e muitos outros profissionais da área da saúde. O que percebemos nos últimos anos é que os valores pagos em salários, patrocínios, propagandas, ingressos e prêmios vêm crescendo. Isso pode insinuar que o esporte além de estar entre um das atividades que contribui consideravelmente na economia global, é uma atividade em ascensão.

As atividades físicas, em geral, são as mais diversas. Diariamente surgem novos estudos e criação dessas práticas. Os profissionais que lidam com o esporte estão sempre se capacitando e se adaptando às demandas que vão surgindo. Os avanços que ocorrem na área influenciam um grande número de pessoas. Por isso, é interessante aos que trabalham com a psicologia do esporte e do exercício que esse avanço seja otimizado e traga o máximo de benefícios aos seus praticantes.

Percebemos que a psicologia do esporte não é uma área recente, apesar de ainda ser desconhecida por muitos. Seus estudos começaram nos países ditos desenvolvidos há mais de 100 anos, chegando aos seus primeiros passos no Brasil na década passada. Essa herança ainda é encontrada hoje em dia, quando até pouco tempo encontrávamos praticamente todas as pesquisas na área em periódicos internacionais. Na prática, também constatamos esses traços, quando a valorização e a possibilidade de atuação da psicologia do esporte e do exercício são maiores nos países que a estudam há mais anos.

Os profissionais que estudam e trabalham com a psicologia do esporte e do exercício, a fim de promovê-la de uma maneira mais eficiente, devem somar seus conhecimentos. Estes são e devem ser de diferentes áreas, por se tratar de uma ciência interdisciplinar e multidisciplinar. Os diálogos e reflexões em diferentes especializações profissionais provavelmente irão trazer conquistas e fortalecer o desenvolvimento dessa promoção. Além disso, é interessante para a área que os profissionais que nela atua estejam sempre promovendo pesquisas, propondo a criação de novos espaços de interação e reflexão, e ampliando e diversificando as competências e potencialidades para uma área que tem muito a ser explorada ainda.

Um dos aspectos que algumas vezes parece ser deixado que lado, mas que deve ser sempre lembrado pelos psicólogos do esporte é o olhar para a pessoa, como um todo. Não podemos deixar de lado ou ignorar as prerrogativas de nossas funções como 
profissionais em psicologia em busca de se ter apenas resultados no contexto esportivo, e deixar de lado o bem estar psicológico dos praticantes de atividades físicas. A comunicação deve ser explorada de maneira condizente com os ensinamentos do curso de Psicologia, possibilitando com que as relações interpessoais no contexto esportivo venham a se desenvolver conforme é esperado eticamente e profissionalmente.

Nota-se nos resultados desta pesquisa que os psicólogos do esporte entrevistados possuem um olhar otimista quanto à evolução que se teve na área nos últimos anos. Existem críticas, incertezas, mas também elogios e a percepção que além de se ter muito a se desenvolver, muito vem sendo feito para esse desenvolvimento. O processo de tornar-se psicólogo do esporte para os entrevistados veio desde antes a graduação em Psicologia na UnB e teve seu momento de maior impacto alguns anos após com as práticas profissionais.

Os departamentos que formam o Instituto de Psicologia da UnB vêm ao longo dos anos pactuando e sendo eficientes na proposta de manter uma formação generalista de seus estudantes. Isso condiz com o esperado nas amplas discussões para a criação das DCN. Julgamos ser condizente para o desenvolvimento dos campos de pesquisa e atuação do psicólogo que também sejam incentivados o aprofundamento dos conhecimentos e especializações dos profissionais que apresentem interesse em dar continuidade aos seus estudos.

De uma maneira mais específica, os resultados obtidos demonstram que existe um processo entre a formação dos psicólogos e o tornar-se psicólogo do esporte e do exercício. Submetidos a uma graduação generalista, como se preza pelas DCN em Psicologia, o psicólogo possui uma base para o seu desenvolvimento, mas pode necessitar de uma complementação teórica e prática para atuar em determinadas especialidades, como no caso da psicologia do esporte e do exercício. Percebemos que os entrevistados entendem a importância de ter tido uma fundamentação teórica generalista ao longo do curso de graduação, mas que ao adentrarem no mercado de trabalho, e especialmente na psicologia do esporte e do exercício, ainda não se sentiam preparados para realizar suas tarefas profissionais.

Podemos frisar também, a partir dos resultados, a importância de uma formação em contato com a prática profissional para a formação do psicólogo. E, principalmente tratar essa soma de teoria e prática na promoção de uma dialética, uma síntese na formação do profissional, sem tratar como uma dicotomia. A prática carrega teoria e a teoria advém também de práticas. Ambas, em um conjunto estão presentes e tem relevância no processo de tornar-se psicólogos do esporte e do exercício.

Propomos que a Psicologia como um todo tenha um contato maior com os psicólogos recém-formados, a fim de perceber como eles vêm o seu processo de formação diante das mudanças propostas pelas DCN de 2011. A compreensão de como esses jovens 
psicólogos se percebem, adentrando profissionalmente, suas dúvidas, comentários sobre o período da graduação e sugestões, tem muito a acrescentar aos que regulamentam as propostas das diretrizes oferecidas ao curso. Esse foi um ponto mencionado nas próprias DCN e que ainda não foram encontrados estudos de pesquisas realizadas, talvez porque pelo curto espaço de tempo, os estudantes dos novos currículos ainda não se formaram. Porém, pesquisas ao longo do curso com esses alunos já poderiam trazer resultados significativos.

Em determinados momentos, ao serem propostas mudanças, apesar dessas possuírem respaldo teórico e científico, cabe-se verificar como está ocorrendo o processo dessas mudanças. Neste estudo, percebemos que a psicologia do esporte e do exercício ainda é uma área que não é de conhecimento amplamente divulgado na Universidade de Brasília, algumas vezes nem sequer é divulgada. Não queremos dizer aqui que achamos que essa área da Psicologia é mais importante que as demais ou que ela deva ser inserida nos currículos de todos os cursos de graduação existentes. Mas que as faculdades e os departamentos de Psicologia deveriam tentar ao menos promover um primeiro contato em áreas ainda não tão consolidadas. Isso teria o objetivo de informar aos alunos que existe um leque de oportunidades que pode ser explorado na Psicologia que vai além do que é possível ser apresentado em um curso de graduação, mesmo com a formação generalista proposta.

O estudante ao ter um primeiro contato com áreas novas pode dar ênfase tanto nas suas escolhas curriculares como buscar maneiras de se capacitar que vão além das teorias vistas dentro da sala de aula. $\mathrm{E}$ isso seria o que se espera quando se propõe uma formação generalista da pessoa, do indivíduo, que se forma em Psicologia. 


\section{REFERÊNCIAS}

Ancona-Lopez, M., \& Maranhão, E. (2004). Parecer CNE/CES n. 0062/2004 - Diretrizes Curriculares de Psicologia. Retirado dehttp://www.anaceu.org.br/legislacao/pareceres_cne/parecer_05. html.

Angelo, L. F. (2003) Educação de corporeidade e psicologia do esporte: estudo de caso de um grupo esportivo (Dissertação de mestrado, Universidade de São Paulo, São Paulo, Brasil).

Araújo, D. (2002). Definição e história da psicologia do desporto. Em Serpa, S. e Araújo, D. Psicologia do Desporto e do Exercício (pp. 9-51). Lisboa: FMH Edições.

Barbanti, V. J. (2006) A biodinâmica do movimento humanos e as suas relações interdisciplinares. Cidade: Estação Liberdade.

Bastos, A. V. B., \& Gondim, S. M. G. (2010). O trabalho do psicólogo no Brasil. Porto Alegre: Artmed.

Bastos, A. V. B. (2002). Perfis de formação e ênfases curriculares: o que são e por que surgiram? Revista do Departamento de Psicologia - UFF, 14(1), 31-58.

Becker, H. (2000). Observação social e estudos de caso sociais. Em H. Becker. Métodos de pesquisa em ciências sociais (pp. 117-133). São Paulo: Hucitec.

Becker Junior, B. (2000). Manual de psicologia do esporte e exercício. Porto Alegre: NOVAPROVA.

Bernardes, J. S. (2004). O debate atual sobre a formação em psicologia no Brasil: análise de documentos de domínio público. Estudos e Pesquisas em Psicologia, 3(2), 2004. Disponível em: www.revispsi.uerj.br

Bracht, V. (1995) As ciências do esporte no Brasil. Em A. Ferreira Neto, S. V Goellner, V e Inicial do nome. Bracht (Orgs.) As ciências do esporte no Brasil. Campinas: Autores Associados.

Brasil, buscar como cita um ministério (1962). Currículo mínimo para os cursos de Psicologia. Brasília: Ministério da Educação. Retirado dehttp://www.abepsi.org.br/portal/wpcontent/uploads/2011/07/1962curriculominimoparaoscursosdepsicologia.pdf

Caspersen, C.J. ; Powell, K.E. \& Cristensen, G. M. (1985). Physical activity, exercise, and physical fitness: definitions and distinctions for health-related reseach. Public Health Reports, 100(2), 172-179.

Carvalho, M. T. M., \& Sampaio J. R. (1997). A formação do psicólogo e as áreas emergentes. Psicologia: Ciência e Profissão, 17, 14-19. 
Conselho Federal de Psicologia (1992). Carta de Serra Negra. Brasília: Conselho Federal de Psicologia. Retirado de http://www.abepsi.org.br/portal/wpcontent/uploads/2011/07/1992-cartadeserranegra.pdf

Conselho Nacional de Educação/Câmara de Educação Superior (2004). Diretrizes Curriculares Nacionais para os Cursos de Graduação em Psicologia. Brasília: Autor.

Cox, R. H., Qiu, Y., \& Liu, Z. (1993). Overview of Sport Psychology. In (Singer, R; Murphy, M. \& Tennant, L. K., (Orgs) Handbook of Research on Sport Psychology, (pp. 1-31). Cidade: Editora.

Dobranszky, I. A. (2005). Subjetividade no esporte: o impacto da subjetividade do técnico na constituição de uma equipe de triatlon (Tese de doutorado, Pontifícia Universidade Católica de Campinas, Campinas, Brasil).

Duarte, Newton. (2004). Formação do indivíduo, consciência e alienação: o ser humano na Psicologia de A.N. Leontiev. Cadernos CEDES. Campinas, 24(62), 44-63.

Francisco, A. L., \& Bastos, A. V. B. (1992). Conhecimento, formação e prática: o necessário caminho da integração. Em A. L. Francisco, C. R. Klomfahs \& N. M. D. Rocha (Orgs.). Psicólogo brasileiro: construção de novos espaços (pp. 211-227). Brasília: Conselho Federal de Psicologia.

Feltz, D. (1992). The nature of Sport psychology. In T. Horn (Ed.) Advances in Sport psychology (pp. 3-11). Champaign: Human Kinetics.

Fitz, G. W. (1897). Play as a factor in development. American Physical Educacion Review, 2, pp. 209-215.

Gallati, L. R. (2010). Esporte e clube sócio-esportivo: percurso, contextos e perspectivas a partir de estudo de caso em clube esportivo espanhol (Tese de doutorado, Universidade Estadual de Campinas, Campinas, Brasil). Retirado de http://cutter.unicamp.br/document/?code $=000770298$

Gill, D. L. (1986). Psychological dynamics of Sport. Champaign: Human Kinetics.

Gill, D. L. (2000). Psychological Dynamics of sport and exercise. Champaing: Human Kinects.

Gomes, W. B. (1996). Pesquisa e ensino em psicologia: articulações possíveis entre graduação e pós-graduação. Em R. Carvalho. Repensando a formação do psicólogo: da informação à descoberta (pp. 33-50). Campinas: Alínea.

González-Rey, F. (2002). Pesquisa qualitativa em psicologia: caminhos e desafios. São Paulo: Pioneira Thomson Learning.

Guggenbühl-Craig, A. (1998). Power in the helping professions. Zurich: Spring Publications. Haaken, J. (1988). Field dependence research: A historical analysis of a psychological construct. Signs, 311-330. 
Hermann, E. (1921). The psychophysical significance of physical educacion. American Physical Educacion Review, 26, p.283-289.

Instituto de Psicologia (2000). Projeto Pedagógico do Curso de Graduação do Instituto de Psicologia da Universidade de Brasília. Brasília: Instituto de Psicologia/Universidade de Brasília.

Isberg, L. (1993). Methodological issues in sport psychology. Em S. Serpa, J. Alves, V. Ferreira, \& A. P. Brito (Eds.). Actas do 8.ํ Congresso Mundial de Psicologia do Desporto (pp. 456-458). Lisboa: ISSP, SPD, FMH.

Jones, J., \& Hardy, L. (1990). Stress and performance in sport. New York: John Wiley \& Sons.

Jordão, A. P. M. (2006). Psicologia do esporte. Disponível no site: http://www.psicologia.com.pt/artigos.

Kopnin, Pavel V. (1978). A dialética como lógica e teoria do conhecimento. Rio de Janeiro: Civilização Brasileira.

Kroll, W., \& Lewis, G. (1970). America's first sport psychologist. Quest, 13, 1-4.

Lei no 4.119, de 27 de agosto de 1962. (1962, 17 de dezembro). Dispõe sobre os cursos de formação em Psicologia e regulamenta a profissão de psicólogo. Diário Oficial da União. Retirado de http://www.planalto.gov.br/ccivil_03/LEIS/1950-1969/L4119.htm

Lei n. 5.692, de 11 de agosto de 1971. (1971, 12 de agosto). Fixa diretrizes e bases para o ensino de $1^{\circ}$ e $2^{\circ}$ graus, e dá outras providências. Em São Paulo (Estado). Secretaria da Educação. Diretrizes e bases para o ensino de $1^{\circ}$ e $2^{\circ}$ graus. (pp. 514). São Paulo: IOE.

Markunas, M. (2000). Reabilitação esportiva ou esporte como reabilitação? Em K. Rubio. (Org.) Psicologia do Esporte: interfaces, pesquisa e intervenção. São Paulo: Casa do Psicólogo.

Martens, R. (1987). Coaches Guide to Sport Psychology. Champaign: Human Kinetics.

Marques, M. G. (2003). Psicologia do esporte: aspectos em que os atletas acreditam. Editora da ULBRA.

Marques, J. A., \& Kuroda, S. J. (2000). Iniciação Esportiva: um instrumento para a socialização e formação de crianças e jovens. Em K. Rubio. (Org.). Psicologia do Esporte: Interfaces, Pesquisa e Intervenção. São Paulo: Casa do Psicólogo.

Patrick, G. T. W. (1903). The psychology of football. American Journal of Psychology,14, pp.104-117.

Parecer n. 403/62 do CFE. (19 de dezembro 1962). Brasília: Ministério da Educação. Retirado 
http://www.abepsi.org.br/portal/wpcontent/uploads/2011/07/1962parecern403de196 21.pdf

Peixoto, E. M., \& Yoshida, E. M. P. (2012). Psicologia do esporte e otimização no esporte de alto rendimento. FIEP Bulletin On-line, 82 (2). Retirado de: http://www.fiepbulletin.net/index.php/fiepbulletin/article/view/2457/4553

Pesca, A. D., \& Cruz, R. M. (2011). Estudos de autoeficácia em psicologia do esporte. Revista de Psicologia, (1).

Rebustini, F., \& Machado, A. A. (2012). Dinâmicas sociais e estados de humor. Motriz, Rio Claro, v.18 n.2, p.233-244, abr./jun. 2012

Richardson CR, Faulkner G, McDevitt J, Skrinar GS, Hutchinson DS, Piette JD. Integrating physical activity into mental health services for persons with serious mental illness. Psychiatry Serv 2005 Mar;56(3):324-31.

Rogers, C. R. (?/2001). Tornar-se pessoa. 5. Ed. São Paulo: Martins Fontes.

Rubio, K. (1999). A psicologia do esporte: histórico e áreas de atuação e pesquisa. Psicologia: Ciência e Profissão, 19, 60-69.

Rubio, K. (2000). Encontros e desencontros: descobrindo a psicologia do esporte. Casa do psicólogo Livraria e Editora Ltda. São Paulo, Casa do Psicólogo.

Rubio, K. (2001) O trajeto da Psicologia do Esporte e a formação de um campo profissional. Em K. Rubio (Org.) Psicologia do Esporte: interfaces, pesquisa e intervenção. São Paulo: Casa do Psicólogo.

Rubio, K. (2007). Ética e compromisso social na Psicologia do Esporte. Psicologia Ciência e Profissão,27 (1), 60-69.

Samulski, D. (1992). Psicologia do Esporte. Belo Horizonte: Imprensa Universitária/UFMG.

Samulski, D. (2000). Psicologia do Esporte. São Paulo: Manole.

Silami Garcia, E., \& Lemos, K. L. M. (2002). Temas Atuais VII: Educação Física e Esportes (pp. 9-26) Belo Horizonte: Editora Health

da Silva, S. M. C., de Castro Almeida, C. M., \& Ferreira, S. (2011). Apropriação cultural e mediação pedagógica: contribuições de vigotski na discussão do tema. Psicologia em estudo, 16(2), 219-228.

Singer, R. (1993). Sport Psychology: an integrated approach. Em Serpa, S., Alves, J.,Ferreira, V. e A. Brito. Proceedings of the 8th world congress in sport psychology (pp. 131-146). Lisboa: SPPD - FMH.

Spinato, I.L., Monteiro, L.Z.,\& Santos, Z. M. S. A. (2010). Adesão da pessoa hipertensa ao exercício físico - uma proposta educativa em saúde. Texto contexto - enferm., 19, 2, pp. 256-264.

Thomas, A. (1983). Esporte: Introdução à Psicologia. Rio de Janeiro: Ao livro técnico. 
Triviños, N. S. (1987). Introdução à pesquisa em ciências sociais: a pesquisa qualitativa em educação. São Paulo: Atlas.

Triplett, $N$ (1898). The dynamogenic factors in pacemaking and competition. American Journal of Psychology. 9, 507-553.

Vieira, L. F., V., João Ricardo Nickenig, Oliveira, Leonardo Pestillo de, \& Vieira, José Luiz Lopes. (2010). Psicologia do esporte: uma área emergente da psicologia. Psicologia em Estudo, 15(2), 391-399.

Vigostski, Liev Semionovitch. (1987). Pensamento e Linguagem. São Paulo: Martins Fontes.

Vigotski (1931/2000). A formação social da mente (6a . Ed.) São Paulo: Martins Fontes

Viveiros, L., Moreira, A., Bishop, D., \& Aoki, M. S. (2015). Ciência do Esporte no Brasil: reflexões sobre o desenvolvimento das pesquisas, o cenário atual e as perspectivas futuras. Revista Brasileira de Educação Física e Esporte, 29(1), 163175.

Weinberg, R., \& Gould, D. (2001). Fundamentos da Psicologia aplicada ao exercício e ao esporte. Porto Alegre: ARTMED.

Weinberg, R. S. (2008). Fundamentos da psicologia do esporte e do exercício. 4. Ed. Porto Alegre: Artmed. 
Roteiro de entrevista semiestruturada com os psicólogos do esporte e do exercício

1 - Como se deu a escolha pelo curso de Psicologia?

2 - Quando surgiu o interesse pela Psicologia do Esporte e do Exercício?

3 - Quais foram suas estratégias para se aproximar na Psicologia do Esporte e do Exercício?

4 - Em que momento se viu tornando-se psicólogo do esporte?

5 - Quais são suas críticas, construtivas ou não, em relação a formação do psicólogo na Universidade de Brasília?

6 - Quais são suas sugestões para o avanço da Psicologia do Esporte e do Exercício? 